\title{
The genetic environmental transformation mechanism of coal and oil shale deposits in eastern China's continental fault basins and the developmental characteristics of the area's symbiotic assemblages-taking Huangxian Basin as an example
}

\author{
Dong-Dong Wang ${ }^{1,2} \cdot$ Zeng-Xue Li $^{1} \cdot$ Hai-Yan Liu' ${ }^{1}$ Da-Wei Lyu' · Guo-Qi Dong ${ }^{1}$
}

Received: 20 April 2018 / Published online: 22 April 2019

(c) The Author(s) 2019

\begin{abstract}
Coal and oil shale are two common sedimentary energy sources which are often symbiotically developed in MesozoicCenozoic continental fault basins. However, the mechanisms and characteristics of the symbiotic development are not yet clearly known. In this research study, the typical continental fault basins of eastern China were chosen as examples for the purpose of conducting an examination of the coal and oil shale symbiotic assemblage types, genetic environmental differences, and transformation mechanisms, as well as the development and occurrence characteristics of different assemblage types. Through a large number of investigations, systematic experimental testing, and sequence stratigraphy studies, the following conclusions were obtained: (1) There were five types of coal and oil shale symbiotic assemblages observed in the continental fault basins, (2) The development of coal and oil shale deposits requires a warm and humid climate, stable structure, abundant organic matter supply, a certain water depth, and a lower terrestrial source debris supply. The observed differences were that the water depth conditions were diversified in the study area, as well as the sources, types, and content of the organic matter. (3) The rapid transformations of the coal and oil shale genetic environments were mainly controlled by the tectonic settings and climatic conditions, which were determined to control the changes in the water depths, salinity, redox conditions, and lake productivity of the genetic environments. Also, in the symbiotic assemblages, genetic environment changes had induced the development of oil shale deposits, which gradually evolved into coal genetic environments. (4) In the isochronous sequence stratigraphic framework of the coal and oil shale symbiotic assemblages, the lake expansion system tracts (EST) were determined to be the most beneficial to the growth of all the types of assemblages and were characterized by more assemblage development phases and smaller bed thicknesses. From the early to the late stages of the EST, and from the lakesides to lake centers, the thicknesses of the coal seams in the symbiotic assemblages showed trends of thinning, while the thicknesses of the oil shale deposits exhibited increasing trends. The early stages of high stand system tracts were found to be beneficial to the development of the symbiotic assemblages of coal seams overlying the oil shale. This tract type generally presented large bed thicknesses and distribution ranges. The low stand system tract and the late high stand system tract were determined to be unconducive to the development of the symbiotic assemblages.
\end{abstract}

Keywords Coal and oil shale symbiotic assemblages $\cdot$ Genetic environments $\cdot$ Conversion mechanism $\cdot$ Sequence stratigraphic framework $\cdot$ Occurrence characteristics $\cdot$ Continental fault basin

Edited by Jie Hao

Dong-Dong Wang

wdd02_1@163.com

Hai-Yan Liu

lhylsj@163.com

1 College of Earth Science and Engineering,

Shandong University of Science and Technology,

Qingdao 266590, Shandong, China
2 School of Geosciences,

China University of Petroleum (East China),

Qingdao 266580, Shandong, China 


\section{Introduction}

In geological exploration for energy sources, the symbiotic development phenomenon of coal and oil shale deposits is often seen, such as in China's Fushun Basin (Meng et al. 2012a, b), Huadian Basin (Sun et al. 2013), and Songliao Basin (Bechtel et al. 2012); Ethiopia's Delbi-Moye Basin (Ahmed 2004); and Thailand's Mae Sot Basin (Curiale and Gibling 1994). It can also be seen in the Early Carboniferous strata in northern Canada (Cameron et al. 1994) and is the most prominent in Mesozoic-Cenozoic continental fault basins (Chen 1951; Liu and Liu 2005; Liu et al. 2007, 2012a, b; Liu and Liu 2006). Coal and oil shale are two common sedimentary types, and their respective formation conditions have been deeply studied by many experts and scholars. These formation conditions have included the patterns of the coal's transgressions or regressions in coastal plain areas (peat) (Diessel 1992; Diessel et al. 2000); patterns of the transgressive events of coal deposits (Li et al. 2001); patterns of episodic coal formations (Shao et al. 1992); patterns of coal formations in fault basins ( $\mathrm{Li} \mathrm{1998);} \mathrm{coal} \mathrm{formation}$ patterns in inland lake deltas (Wang 2012); stratified lake patterns of the Wilkins Peak in the Green River Basin of the USA (Bradley and Eugster 1969); playa patterns (Eugster and Surdam 1973); playa complex patterns (Surdam and Stanley 1980); biochemical stratified lake patterns (Desborough 1978); externally stratified lake patterns (Boyer 1982); deep lake oil shale depositional patterns of inland lake basin depression periods (Bechtel et al. 2012); and the oil shale and coal symbiotic deposition patterns of small fault lake bays or limnology (Bai et al. 2010). Moreover, the previous research studies regarding oil shale have mainly focused on the hydrocarbon generation potential of oil shale (Bechtel et al. 2012); organic geochemical characteristics (Sun et al. 1998; Wang et al. 2011); paleo-environment evolution (Meng et al. 2012a, b; Ahmed 2004; Bechtel et al. 2012); and so on. Meanwhile, less research has been focused on the genetic mechanisms of oil shale.

The results of previous related studies confirmed that coal and oil shale are energy sources which have been formed under the conditions of large differences in sedimentary environments. When the two are found to coexist in the same basin closely adjacent to each other in vertical sedimentary sequences or even with inter-beds, it is assumed that there must have been some type of special geological conditions and control function which led to the rapid transformation of both genetic environments.

In 2013, Professor Li Zengxue's research team from the Shandong University of Science and Technology began to pay close attention to and studied symbiotic coal and oil shale deposition. As a result, certain understandings have been achieved in regard to symbiotic coal and oil shale assemblage types, genetic condition differences, and the occurrence of symbiotic assemblages (Wang et al. 2013a, b; Li 2013; Liu et al. 2014; Feng et al. 2015; Lv et al. 2015, 2016, 2017; Li et al. 2016; Wang et al. 2016; Li et al. 2018).

In this study, two typical fault basins (the Yilan Basin of Heilongiiang Province and the Huangxian Basin of Shandong Province) were selected as examples for the examination of coal and oil shale assemblage types, similarities and differences of both genetic environments, and the development and distribution of symbiotic assemblages. Also, the transformation mechanisms of both genetic environments were investigated, and the characteristics and transformation mechanisms of coal and oil shale genetic environments in continental fault basins were systematically illustrated. This study also focused on the development and occurrence regularity of symbiotic assemblages, in order to further enrich the basic theory of energy geology and to provide some guidelines for future multi-energy comprehensive exploration.

\section{Geological backgrounds of typical coal and oil shale symbiotic basins}

In this research study, the Paleogene Dalianhe Formation in the Yilan Basin of Heilongjiang Province and the Paleogene Lijiaya Formation in the Huangxian Basin of Shandong Province were selected as the research objects for the purpose of examining the characteristics of coal and oil shale symbiotic assemblages. The geological characteristics of these typical basins were as follows.

The Yilan Basin is one of China's typical Cenozoic fault basins. It is located in the north branch of the Tanlu fault zone within the eastern China's Yilan-Yitong fault zone. The Yilan Basin is characterized by an unconformity above the pre-Mesozoic granite, and the sedimentary cap cover is the Eocene Paleogene Dalianhe Formation (Fig. 1a, b). Also, the Yilan Basin is considered to be a semi-graben basin with an EW trend and a lean to the SE, where the filling strata are, from bottom to top, the Eocene Dalianhe Formation $\left(\mathrm{E}_{2-3} d\right)$ consisting of a sand conglomerate member $\left(\mathrm{E}_{2-3} d^{1}\right)$; coal and oil shale member $\left(\mathrm{E}_{2-3} d^{2}\right)$; semideep lake-deep lake low-grade oil shale member $\left(\mathrm{E}_{2-3} d^{3}\right)$; and sand shale member $\left(\mathrm{E}_{2-3} d^{4}\right)$ (Wang et al. 2013a, b).

The Huangxian Basin, a coal-bearing faulted basin, was formed in the Mesozoic and Cenozoic, located in Huangxian and Penglai in northeastern Shandong Province, eastern China (Fig. 1a). It measures $28 \mathrm{~km}$ in the east-west direction and $12-15 \mathrm{~km}$ in the north-south direction, with an area of $372.8 \mathrm{~km}^{2}$. The basin is bounded by the Bohai Sea in the west and northwest and the Late Archean Jiaodong Group (Ar4j), Paleoproterozoic Fenzishan Group, Cretaceous Qingshan Group, and Cenozoic strata to the east and south. It is 


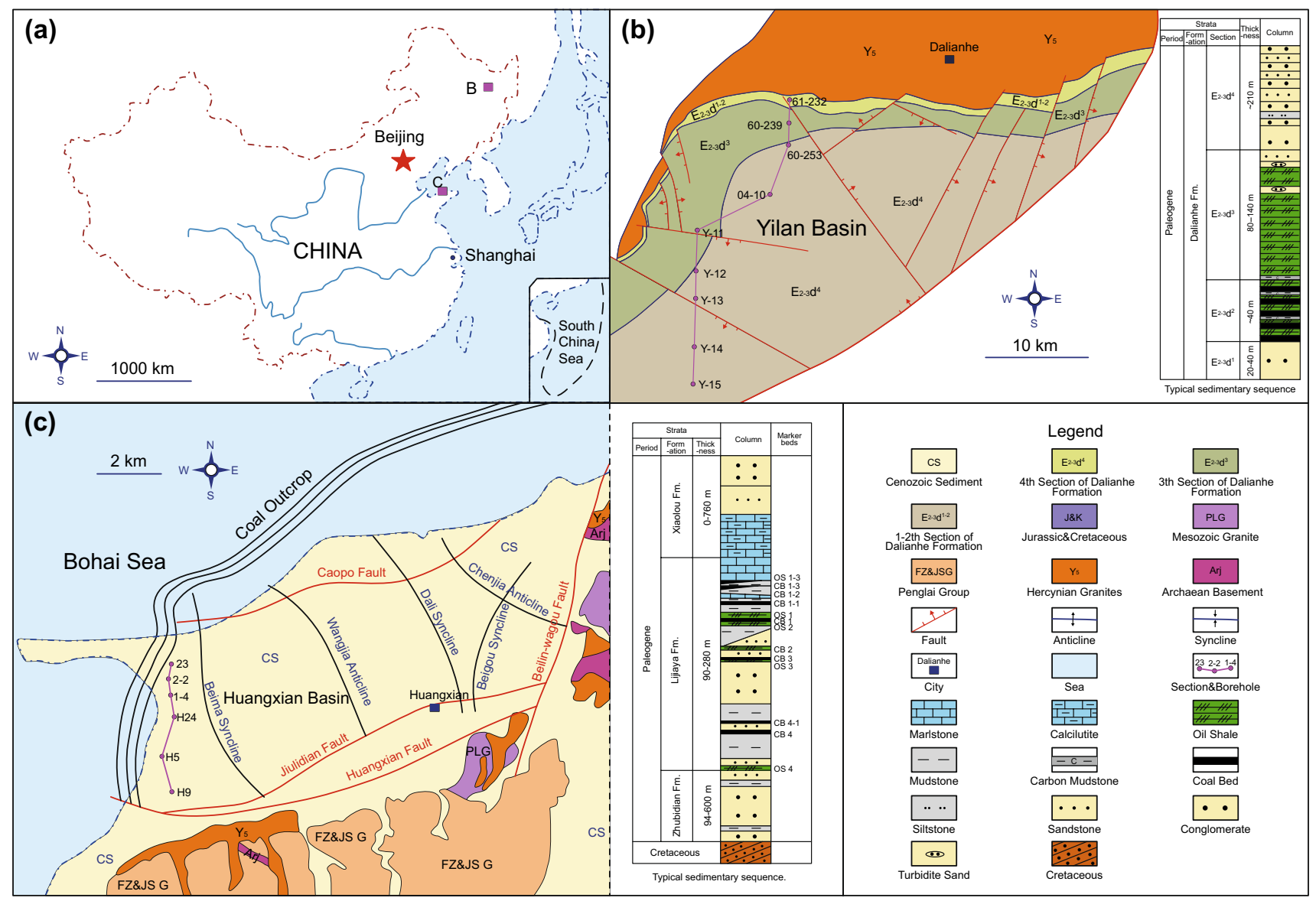

Fig. 1 Geological map of typical coal and oil shale symbiosis basin. a Location of the Huangxian Basin and Yilan Basin; b Yilan Basin geological map and the typical sedimentary sequence; and $\mathbf{c}$ Huangxian Basin geology and the typical sedimentary sequence

bounded in the east by the NNE-trending Beilinyuan-Wagou Fault, the NNE-trending Pingdu-Jiehe Fault to the west, and the sub-EW-trending Huangxian Fault to the south (Fig. 1c). The Paleogene strata are composed of the Zhubidian Formation, Lijiayan Formation, and Xiaolou Formation from oldest to youngest (Fig. 1c). The 94-600-m-thick Zhubidian Formation is composed of variegated pebbly sandstone intercalated with mudstone, uneven coalbeds, celadon green or dark purple siltstone intercalated with coarse sandstone and mudstone and unconformably overlies Cretaceous strata. The Lijiayan Formation is 90-280 m thick, with an average of $216 \mathrm{~m}$, and conformably overlies the Zhubidian Formation. It comprises mudstone, sandstone, marlstone, coalbeds, and oil shale and contains Paracypris, Shantunella $S p$., Bythocypris, and Gastropods fossils (Wang et al. 2007a, b). The Xiaolou Formation has a maximum residual thickness of over $760 \mathrm{~m}$ and comprises purple sandstone, thin-tomedium thick-bedded siltstone, mudstone, and claystone. It is dominated by celadon or yellow-green calcareous mudstone and conformably overlies the Lijiayan Formation (Lv et al. 2017).

\section{Coal and oil shale symbiotic assemblage types and the differences in their genetic conditions}

\subsection{Typical coal and oil shale symbiotic assemblage types}

Coal and oil shale symbiotic basins exist both in China and internationally. The results of previous research studies have shown that coal and oil shale symbiotic assemblages mainly appear in continental fault basins and rarely in depression basins. There are five types of coal and oil shale symbiotic assemblages normally found in the continental fault basins (Wang et al. 2016; Li et al. 2016) (Fig. 2). These are as follows, according to the formations from bottom to top: 1) oil shale/coal assemblages (OS-C); 2) coal/oil shale assemblages (C-OS); 3) coal/oil shale/coal assemblages (C-OS-C); 4) oil shale/coal/oil shale assemblages (OS-C-OS); and 5) coal/other sediment/oil shale assemblages (C-M/S-OS). 
(a)
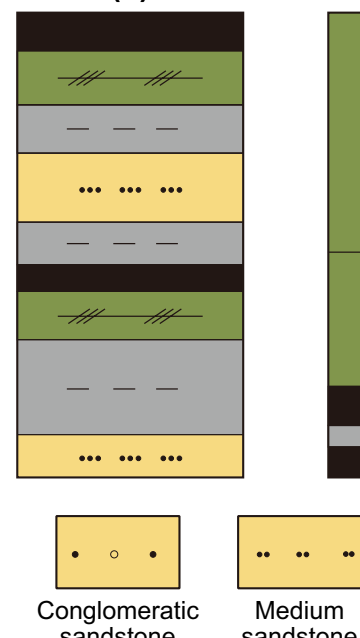

sandstone sandstone (b)
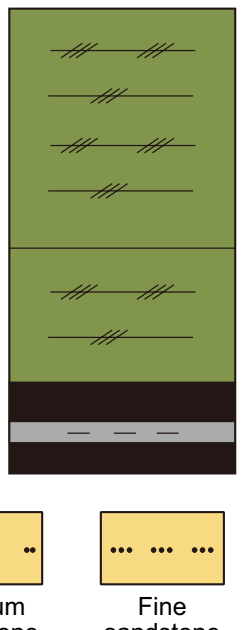
sandstone (c)
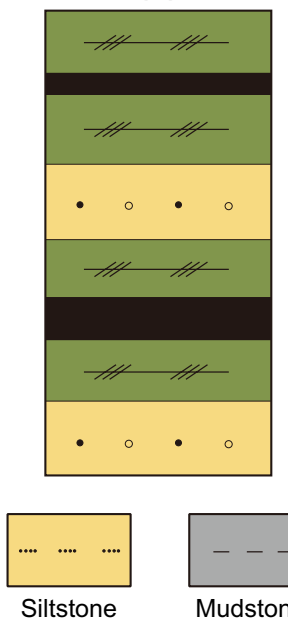

Siltstone (d)
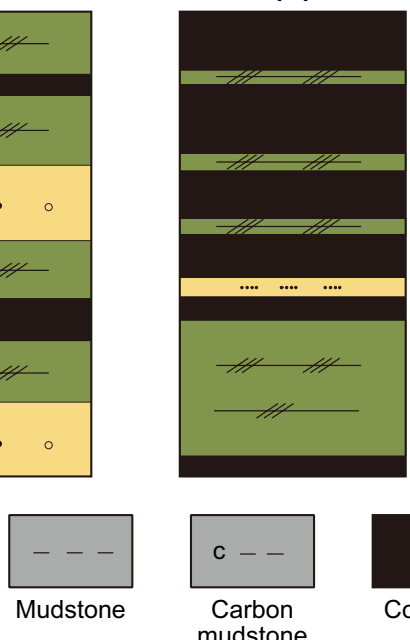

(e)
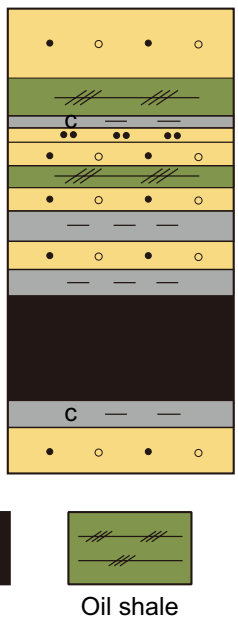

Fig. 2 Types of coexistence of coal and oil shale: a oil shale/coal assemblage (OS-C); b coal/oil shale assemblage (C-OS); $\mathbf{c}$ oil shale/coal/oil shale assemblage (OS-C-OS); $\mathbf{d}$ coal/oil shale/coal assemblage (C-OS-C); and e coal/mud or sand/oil shale assemblage (C-M/S-OS)

\subsection{Comparative analysis of the developmental conditions of coal and oil shale}

\subsubsection{Sources of organic matter}

Coal deposits have evolved from higher plants (woody, herbaceous, and so on) and/or lower plants (algae, and so on) which have been converted to peat and/or sapropel through petrification and/or saprofication, which was then followed by diagenesis and metamorphism into different metamorphic degrees of coal (Stach 1990). It is known that humolite was mainly formed from higher plants, while sapropel was formed from lower plants, and humic-sapropelic coal represented a transition state. It has been found that in different types of coal deposits, the types and content of the organic macerals are different. Peat bogs are known to be the main site of coal-forming plant development, peat accumulation, and preservation, in which the coal development generally requires relatively stable structural conditions and less terrigenous detrital material input. When the terrigenous detrital material supplies of the peat bogs are cut off by some mechanism, it becomes more beneficial to the development of the peat bog, as well as the accumulation and preservation of the peat. These environmental factors are known to be conducive to the continuous occurrences of coal formations (McCabe 1984; Diessel 1992).

Oil shale is a type of rock rich in organic matter. It is mainly derived from algae, some lower biological debris, or higher plant residues (Zhang et al. 1985; Liu 2008; Liu et al. 2007; Luo et al. 2011; Jia 2012; Sun 2013). The growth rates of natural plankton (such as algae) in lakes can fluctuate and thrive with seasonal changes such as temperature, seasonal cycles, and water mixtures (Kelts 1988; Wu et al. 1998a, b; Liu et al. 2001; Zhu et al. 2005). For example, stormcarried minerals rich in nutrients (such as iron ions) enter lake water, which leads to the seasonal thriving of different taxa of plankton with high productivity (Hecky and Fee 1981; Hay 1990; Sancetta 1996; Riboulleau et al. 2003). The direct consequence is the lakes' authigenic organic matter deposits in the strata in a laminated form (Kemp 1996). The algae blooms in lakes can also induce carbonate deposits in the surface water (Kelts 1988). In addition, oil shale is continuously depositing in locations far away from terrigenous debris, and the injection of terrigenous debris is not conducive to the stratification of the water bodies (Stephen 1998; Bohacs et al. 2000).

\subsubsection{Water conditions}

The sedimentary environments which are conducive to coal formation mainly include river alluvial plains, (fan) delta plains, lakeside swamps, coastal plains, and lagoon-tidal flat peat swamp environments. The swamp areas are transition states between water and land, where the water masses are shallow with only small changes in the water depths. The swamp environments have been found to be very sensitive water environments. In accordance with the hydrodynamic conditions, lithologic assemblage, and sediment characteristics of swamp environments, they can be divided into closed flow swamps, peat bogs, and overlying water swamps. The peat bogs are defined as where peat has developed and accumulated in a swamp environment (McCabe 1984; Diessel 1992; Yang and Han 1979; Li 2005). 
The sedimentary environments which are conducive to the development of oil shale mainly include lakes, lake swamps, lagoons, and marine transitional environments which are dominated by the genesis of lake facies (Liu et al. 2007). There have been many research studies conducted regarding the genesis of oil shale. In particular, there has been extensive research conducted on the oil shale located in the Wilkins Peak Member of the Green River Basin in the USA. Multiple genetic patterns have been successively established. These patterns highlight the importance of water stratification, which can be thermal stratification caused by temperature or chemical stratification caused by salinity. It has been determined that thermal stratification is generally not stable, while salinity stratification is more stable and persistent (Deng and Qian 1993; Riboulleau et al. 2003; Wang 2005; Xu et al. 2006). However, either type of stratification will require a certain water depth (Liu et al. 1998). The water depth is a necessary condition of the water stratification rather than a sufficient condition. For example, the lake bottom of Lake Lugano in Switzerland has a water depth of $270 \mathrm{~m}$ and still has periodic oxygen enrichment. Also, Maar Lake on the Leizhou Peninsula shows a thermocline at a water depth of 8 to $13 \mathrm{~m}$ (Chu et al. 2000). In regard to offshore basins such as the Huangxian Basin, transgressions can lead to the lake water presenting salinity stratification, with massive deaths of freshwater animals, and flourishing bacteria, and algae phytoplankton, which is known to be conducive to the development of oil shale (Xu et al. 2006; Zhou et al. 2006). The massive development of some oil shale has even been determined to be closely related to the rise of global sea levels and oceanic anoxic events (Liu et al. 1992, 2007).

\subsubsection{Climate conditions}

Climate conditions are the fundamental factors controlling the exogenous effects and biological reproduction processes on the Earth's surface. The changes in climate conditions affect the acidity, salinity, and redox environments of the water in sedimentary basins and thereby influence the formation and distribution of organic matter in sedimentary basins.

The development of peat bogs, as well as the accumulation of coal peat, requires warm and humid climate conditions. Under the conditions of warm and humid climates, the vegetation conditions remain stable and the precipitation is rich. These types of environments are beneficial for the growth and reproduction of plants, as well as the preservation of organic matter. In addition, climatic conditions affect the type of coalification, thereby influencing the type and content of organic macerals in the coal deposits (McCabe 1984; Diessel 1992; Yang and Han 1979; Li 2005).

Oil shale development is also more apparent in warm and wet weather conditions and has been verified by paleontological characteristics and biomarkers such as sporopollen in the Maoming Basin of Guangdong (Liu et al. 2007); Huangxian Basin of Shandong (Wang et al. 2001); Wucheng Basin of Tongbai (Zhou et al. 2006); Qinxian Basin of Guangxi (Yan et al. 2006); Fushun Basin of Liaoning (Liu 2008); and Yilan Basin of Heilongjiang (Liu et al. 2012a, b). On the one hand, the warm and humid climate conditions are conducive to the development of stable vegetation. This leads to low supplies of inorganic debris in the lake, which can then carry a large amount of dissolved nutrients, resulting in greatly improved productivity in the lake. On the other hand, abundant precipitation is beneficial in forming deep lakes which are conducive to the formation of perennial stable water stratification and reduction conditions, as well as the preservation of organic matter (Liu et al. 2007; Liu 2007). Although the Green River Formation in the Green River Basin of the USA has more developed evaporite and oil shale interlayers, the climate in the area was still warm and humid during the development of the oil shale (Eugster and Surdam 1973; Surdam and Stanley 1980).

\subsubsection{Tectonic conditions}

The development of peat bogs, along with the stable accumulation of peat, requires stable slowly settling tectonic environments. Therefore, locations with severe tectonic activities are not conducive to the emergence and long-term development of peat swamps (Diessel 1992; Yang and Han 1979; Li 2005). The development and accumulation of oil shale are also affected by tectonics. In a fault basin, the synsedimentary faults influence the formation and accumulation of oil shale by controlling the sedimentary environment. The oil shale tends to be mainly distributed on the thrown side of the basin-controlling fault with the greater thickness. The secondary synsedimentary faults control the changes in the sedimentary thickness, lithology, petrographic facies, and petroliferous shale of a basin, and the oil content in the oil shale near the fault site will be increased. During the rapid settlement period of tectonics, the deposition rate of the sediment is relatively large, while the supply of organic matter tends to be relatively insufficient, which often leads to oil shale with low oil content. During the slow subsidence period of tectonics, the supply of terrigenous debris is low, while that of the organic matter is high. Also, the water mass will be deep and stable, which is known to be conducive to the formation of oil shale with high oil content (Liu et al. 2007).

\subsubsection{Summary}

The development of coal and oil shale requires warm and humid climatic conditions, relatively stable tectonic conditions, rich organic matter supplies, certain water depths, 
and less terrigenous detrital material. First, both material sources include different proportions of higher and lower plant matter. The development of coal is generally in peat bog environments with shallow overlying water. Meanwhile, the water depths of the oil shale development environments may vary greatly, dominated by the stable stratification of lakes. Second, the coal-forming materials are dominated by higher plants, and the organic matter of oil shale is mainly sourced from lower plants. Therefore, coal and oil shale development conditions present a large gap. However, there still are many similar or overlapping characteristics. For example, under certain geological conditions, both genetic environments may show rapid transformations, which further develop the coal and oil shale symbiotic assemblages (Wang et al. 2007a, b; Liu et al. 2012a, b; Li 2013; Wang et al. 2013a, b). The development of different types of coal and oil shale symbiotic assemblages reflects the transformations and repetition diversities of both genetic environments.

\section{Coal and oil shale genetic environmental transformation mechanisms}

In this research study, in order to more deeply analyze the rapid conversion mechanisms of coal and oil shale genetic environments in the Oil 2-Coal 1-Oil 1 symbiotic assemblage (OS-C-OS), the Oligocene Lijiaya Formation of the Beizao Coal Mine of the northwestern Huangxian Basin was selected as the study object. Then, through systematic sampling and kerogen microscopy, as well as total organic carbon, major and trace element and organic carbon stable isotope analyses, this study attempted to analyze the transformation process characteristics of the coal and oil shale genetic environments.

\subsection{Samples and methods}

The sampling which was completed in this study was coal mine underground sampling, and the sampling strata included Oil $2^{-2}$, interlayer, Oil $2^{-1}$, Coal 1, and Oil 1 (from the bottom to the top). There were ten samples collected, which were labeled from bottom to top as BZ1 to BZ10, as shown in Fig. 3. Due to restrictions in the underground working conditions, the sample spacing varied.

This study's kerogen microscopy test was completed at the National Geological Laboratory Test Center using a Zeiss A1 microscopic detection instrument. The procedure for the kerogen microscopy test was based on The Identification and Statistical Methods of Whole-rock Photomicrographic Components (SY/T 6414-2014).

The total organic carbon and kerogen carbon isotope tests were completed at the Research Center of the Wuxi Institute of Petroleum Geology, Sinopec Petroleum Exploration and

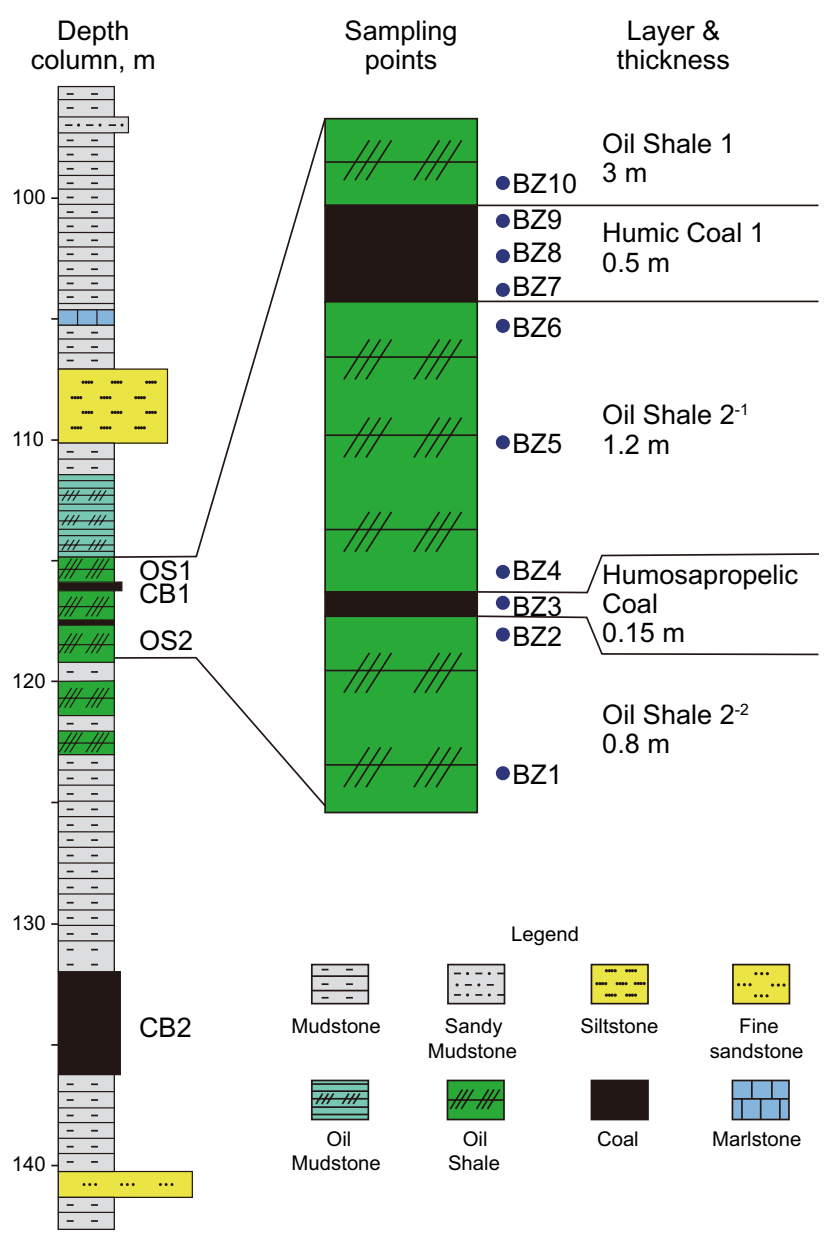

Fig. 3 Sedimentary sequence and sampling points of the coal and oil shale symbiotic assemblages in the north of Huangxian Basin (Beizao coal mine underground). Sedimentary sequence according to the nearby hole BH6; location of the borehole BH6 is shown in Fig. 1c

Development Research Institute. The total organic carbon test equipment was a CS-200 carbon sulfur analyzer (YQ404-06), and the test procedure was based on The Measurement of Total Organic Carbon in Sedimentary Rock (GB/ T19145-2003). The kerogen carbon isotope test equipment included a DELTA PLUS V stable isotope mass spectrometer (YQ3-12-08), and the procedure for the test was based on The Organic Geochemical Analysis Method of Geological Samples Part 2: Organic Carbon Stable Isotope Measurement and Isotope Mass Spectrometry (GB/T18340.2-2010).

The major and trace element tests were completed at the Nuclear Industry Analysis and Test Research Center. The trace element test equipment was a Nex ION300D plasma mass spectrometer (10742), and the test was based on Silicate Rock Chemical Analysis Method Part 30: Amount Measurement of 44 Elements (GB/T 14506.30 2010). The major element test equipment included an $\mathrm{AB} 104 \mathrm{~L}$ X-ray fluorescence spectrometer (10271), AL104 X-ray fluorescence spectrometer (10273), and Axiosm AX X-ray 
fluorescence spectrometer (10482). The procedure for the test was based on Silicate Rock Chemical Analysis Method Part 14: Amount Measurement of Ferrous Oxide (GB/T 14506.14 2010), and Silicate Rock Chemical Analysis Method Part 28: Amount Measurement of 16 Primary and Secondary Components (GB/T 14506.28 2010).

\subsection{Results of the experimental testing and discussion}

\subsubsection{Organic matter and the paleo-productivity characteristics of the coal and oil shale symbiotic assemblages}

For the Oil 2-Coal 1-Oil 1 symbiotic assemblage, the kerogen microscopy results for the Oligocene Lijiaya Formation of Beizao Coal Mine in the northwestern section of the Huangxian Basin showed that the organic matter in the coal and oil shale symbiotic assemblages mainly contained two parts: organic matter of terrigenous higher plants and lake authigenic organic matter (algae and so on), as detailed in Table 1. In the oil shale samples, the organic matter content of terrigenous higher plants accounted for $22.2 \%$ of the entire rock formation on average and $53.3 \%$ of the total organic matter. The lake authigenic organic matter accounted for $20.1 \%$ of the entire rock formation and $46.7 \%$ of the total organic matter. In Coal 1, the organic matter content of terrigenous higher plants accounted for $97.1 \%$ of the entire rock formation on average and $99.5 \%$ of the total organic matter. It was determined that the lake authigenic organic matter accounted for $0.45 \%$ of the entire rock formation and $0.46 \%$ of the total organic matter. Therefore, it was found that the coal in the area had the characteristics of humolite. In the interlayers of Oil $2^{-1}$ and Oil $2^{-2}$, the organic matter content of terrigenous higher plants accounted for $46.0 \%$ of the entire rock formation and $70.7 \%$ of the total organic matter. The lake authigenic organic matter accounted for $19.1 \%$ of the entire rock formation and $29.3 \%$ of the total organic matter. Therefore, it was determined that the interlayer had the characteristics of humic-sapropelic coal. The top and bottom of Coal 1 were very similar to oil shale, where the sapropelitic content had increased, while a rare sapropelitic group was observed to exist in the middle section. Also, in Coal 1 (from top to bottom), the vitrinite and mineral content levels were slightly increased, while the exinite and inertinite content levels had decreased to a certain extent. In the Oligocene Oil 2-Coal 1-Oil 1 symbiotic assemblage of the Huangxian Basin, the TOC and $\delta^{13} \mathrm{C}$ values were observed to be higher in the coal seam member than in the oil shale member and presented a tendency of a gradual increase in the oil shale member from bottom to top. In addition, the $\mathrm{Ba} /$ $(\mathrm{Zr}+\mathrm{Rb})$ ratio suddenly appeared at the initial stage of the development of oil shale and then gradually decreased and reached a minimum value at the coal seam (Fig. 4).

Table 1 Kerogen microscopy test data of coal and shale symbiotic assemblage of Huangxian Basin

\begin{tabular}{|c|c|c|c|c|c|c|c|c|c|c|c|}
\hline \multicolumn{2}{|l|}{ Component } & \multicolumn{10}{|c|}{ Number and component content ( $\%$ of whole rock) } \\
\hline Group & Maceral & BZ1 & BZ2 & BZ3 & BZ4 & BZ5 & BZ6 & BZ7 & BZ8 & BZ9 & BZ10 \\
\hline \multirow[t]{4}{*}{ Sapropelinite } & Layered alginite & 11.20 & 21.86 & 19.08 & 1.85 & 22.78 & 11.62 & 0.00 & 0.00 & 0.61 & 0.00 \\
\hline & Bituminite & 7.80 & 6.96 & 0.00 & 0.00 & 0.00 & 0.00 & 0.00 & 0.00 & 0.00 & 11.90 \\
\hline & Amorphous & 0.00 & 0.00 & 0.00 & 0.00 & 0.00 & 24.52 & 0.74 & 0.00 & 0.00 & 0.00 \\
\hline & Subtotal & 19.00 & 28.82 & 19.08 & 1.85 & 22.50 & 36.20 & 0.74 & 0.00 & 0.61 & 11.90 \\
\hline \multirow[t]{3}{*}{ Exinite } & Sporinite & 0.00 & 0.00 & 0.00 & 22.75 & 0.00 & 0.00 & 9.15 & 7.07 & 6.36 & 0.00 \\
\hline & Liptodetrinite & 0.00 & 0.00 & 14.22 & 0.00 & 0.00 & 0.00 & 21.88 & 3.65 & 4.90 & 0.00 \\
\hline & Subtotal & 0.00 & 0.00 & 14.22 & 22.75 & 0.00 & 0.00 & 31.01 & 10.70 & 11.26 & 0.00 \\
\hline \multirow[t]{3}{*}{ Vitrinite } & Hydrogen-rich vitrinite & 0.00 & 0.00 & 0.00 & 0.00 & 0.00 & 0.00 & 0.00 & 0.00 & 1.59 & 0.00 \\
\hline & Normal vitrinite & 10.60 & 7.70 & 26.40 & 14.80 & 11.00 & 15.14 & 65.39 & 82.45 & 82.37 & 11.54 \\
\hline & Subtotal & 10.60 & 7.70 & 26.40 & 14.80 & 11.00 & 15.10 & 65.40 & 82.40 & 83.96 & 11.50 \\
\hline \multirow[t]{4}{*}{ Inertinite } & Fusinite & 0.00 & 0.00 & 0.00 & 0.00 & 0.00 & 0.00 & 0.25 & 0.00 & 0.00 & 0.00 \\
\hline & Funginite & 0.00 & 0.00 & 0.00 & 0.00 & 0.00 & 0.00 & 0.00 & 0.00 & 0.37 & 0.47 \\
\hline & Inertodetrinite & 7.10 & 9.32 & 5.40 & 5.98 & 7.72 & 3.84 & 2.47 & 3.77 & 0.00 & 6.24 \\
\hline & Subtotal & 7.10 & 9.30 & 5.40 & 6.00 & 7.70 & 3.80 & 2.75 & 3.80 & 0.37 & 6.67 \\
\hline \multirow[t]{2}{*}{ Secondary organic components } & $\begin{array}{l}\text { Hydrogen-rich second- } \\
\text { ary component }\end{array}$ & 0.00 & 0.00 & 0.00 & 0.00 & 0.00 & 0.00 & 0.00 & 0.00 & 1.23 & 0.00 \\
\hline & Subtotal & 0.00 & 0.00 & 0.00 & 0.00 & 0.00 & 0.00 & 0.00 & 0.00 & 1.23 & 0.00 \\
\hline Mineral bitumen matrix & & 0.00 & 13.54 & 0.00 & 0.00 & 0.00 & 0.00 & 0.00 & 0.00 & 0.00 & 0.00 \\
\hline Mineral & & 63.30 & 40.62 & 34.90 & 54.62 & 58.50 & 44.88 & 0.12 & 3.06 & 2.57 & 69.85 \\
\hline
\end{tabular}

Test unit: National Geological Experimental Testing Center 


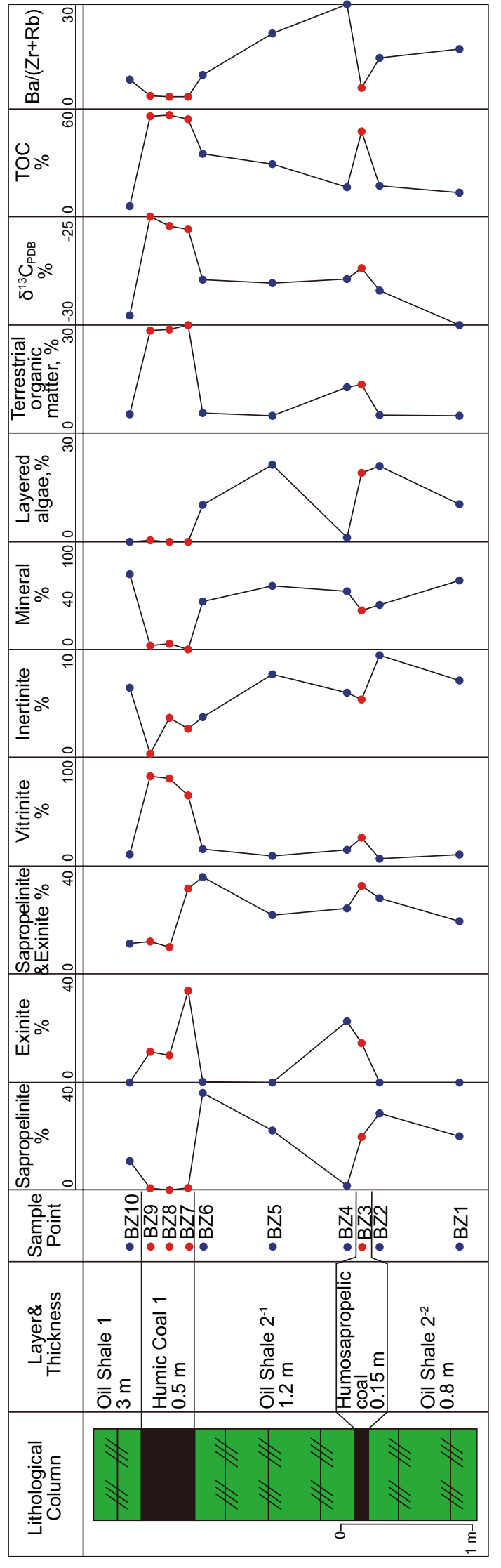

In the vertical direction, the sapropelitic content in the oil shale member (particularly in Oil $2^{-1}$ ) was observed to display an increasing trend from bottom to top. Meanwhile, the vitrinite + inertinite + exinite content was found to have slightly decreased, which reflected a gradual increase in the lake's productivity. When studying the coal and oil shale symbiotic assemblages in the Huangxian Basin, Wang et al. $(2007 a, b)$ determined that the content of the higher plant components in the oil shale near the coal seam was higher. Furthermore, in the coal seam near the oil shale, the content of the lower plant components (algae) was also higher and was characterized by rich hydrogenation. All of the aforementioned results reflected the transition state between the coal and oil shale in the coal and oil shale symbiotic assemblages. When terrigenous organic matter is less injected into lake environments, the high value of the total organic carbon (TOC) generally corresponds to high lake productivity (Meng 2010), and a higher $\delta^{13} \mathrm{C}$ value can also reflect a higher initial lake productivity (Yin 2008). So, the tendency of TOC and $\delta^{13} \mathrm{C}$ values to gradually increase in the oil shale member from bottom to top reflects a gradual increase in the productivity of the lakes. The $\mathrm{Ba} /(\mathrm{Zr}+\mathrm{Rb})$ ratio can potentially reflect the relative content of marine biogenic and terrigenous genetic elements to a certain extent and may also indicate changes in the marine productivity. Generally speaking, the higher the ratio was, the higher the reflected marine productivity would be (Qing et al. 2005). The ratio was found to be particularly high at the bottom of Oil $2^{-1}$, which may have been a reflection of the development of the oil shale which was related to the transgression (Wang et al. 2000; Xu et al. 2006; Zhou et al. 2006; Lv et al. 2017). Subsequently, the ratio gradually decreased, which indicated that the influence of the transgression had gradually decreased.

\subsubsection{Paleo-water depth and redox condition characteristics in the coal and oil shale symbiotic assemblages}

In the Oligocene Oil 2-Coal 1-Oil 1 symbiotic assemblage of the Oligocene Lijiaya Formation of the Beizao Coal Mine in the northwestern section of the Huangxian Basin, the paleo-water depth and redox conditions of the coal and oil shale formations could be roughly determined by the special trace element content. The main trace and major elements of the samples are shown in Tables 2 and 3, respectively.

In the Oligocene Oil 2-Coal 1-Oil 1 symbiotic assemblage, the evolution of $\mathrm{Al}, \mathrm{Mn}, \mathrm{Cr}, \mathrm{Ni}, \mathrm{FeO}$ content and $\mathrm{Mn} / \mathrm{Fe}$ ratio is relatively consistent in the vertical direction, showing that the $\mathrm{Al}, \mathrm{Mn}, \mathrm{Cr}, \mathrm{Ni}, \mathrm{FeO}$ content and $\mathrm{Mn} / \mathrm{Fe}$ ratio of the oil shale are higher than those of the coal seam, and they reach a maximum value in the early stage of development of oil shale and then decrease gradually and reached their minimum value at the coal seam. The ratios of the $\mathrm{Cu}$ / 


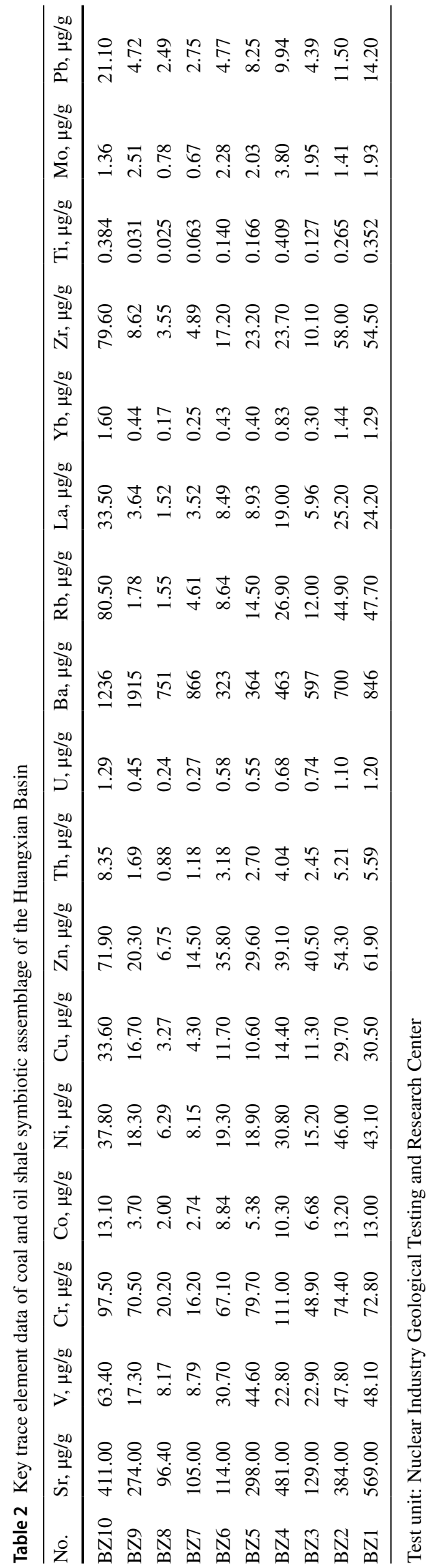

$\mathrm{Zn}$ were mainly between 0.28 and 0.55 , while those of the sample at the top of Coal 1 were only 0.82 . The $\mathrm{V} /(\mathrm{V}+\mathrm{Ni})$ ratio was found to range between 0.43 and 0.70 , and the $\mathrm{Ni} /$ Co ratio was less than 5 (Fig. 5).

In the strata, the levels of $\mathrm{Al}$ and $\mathrm{Mn}$, as well as the $\mathrm{Mn} /$ $\mathrm{Fe}$ ratio, were found to have increased with the greater water depths (Xue 2013). Furthermore, it was determined that the farther from the shore it was, the higher the $\mathrm{Ca} /$ $\mathrm{Si}$ ratio would be, and the deeper the water was, the lower the terrigenous matter would be (Liang et al. 2015). In the Oligocene Oil 2-Coal 1-Oil 1 symbiotic assemblage of the Huangxian Basin, the water depth of the oil shale formation environment was greater than that of the coal formation environment. Also, it was observed that during the early formation stage of the oil shale, the water depth had suddenly increased, which was followed by a gradual decreasing trend, with a minimum being reached during the coalforming period. The water depth presented the regularity of gradually becoming shallower following a sudden deepening trend.

The elements in the strata can also potentially reflect the redox conditions of a sedimentary period. For example, the higher the content levels of $\mathrm{Cr}, \mathrm{Ni}$, and other elements were, the stronger the reduction conditions would be. The $\mathrm{V} /(\mathrm{V}+\mathrm{Ni})$ and $\mathrm{Ni} / \mathrm{Co}$ ratios are also good indicators of the water redox conditions (Jones and Manning 1994; Hatch and Leventhal 1992; Tonger et al. 2004; Meng et al. 2012a, b; Sun 2013). If the $\mathrm{V} /(\mathrm{V}+\mathrm{Ni})>0.54$, this indicates an anaerobic sedimentary environment. Also, if the $\mathrm{V} /(\mathrm{V}+\mathrm{Ni})$ is in the range of $0.46-0.54$, this reflects an oxygen-lean sedimentary environment, and a $\mathrm{V} /(\mathrm{V}+\mathrm{Ni})<0.45$ denotes an oxygen-rich sedimentary environment. A high $\mathrm{Ni} / \mathrm{Co}$ value reflects reduction conditions, and a low value reflects oxidation conditions. The research conducted by Xiong and Xiao (2011) showed that a Ni/Co $>7$ reflects reduction conditions, and a Ni/Co which ranges between 5 and 7 will indicate anaerobic and sub-reducing environments which are not beneficial for water stratification. Furthermore, a $\mathrm{Ni} / \mathrm{Co}<5$ tends to reflect an oxidizing environment. A high $\mathrm{Cu} / \mathrm{Zn}$ value is known to indicate oxidizing conditions, and a low value reflects reducing conditions (Deng and Qian 1993; Xiong and Xiao 2011)also determined that a Cu/ $\mathrm{Zn}<0.21$ reflects reduction conditions. Moreover, a $\mathrm{Cu} / \mathrm{Zn}$ which ranges from 0.21 to 0.38 tends to reflect a weak reduction, and a $\mathrm{Cu} / \mathrm{Zn}$ ranging between 0.38 and 0.50 reflects reduction and oxidation conditions. $\mathrm{A} \mathrm{Cu} / \mathrm{Zn}$ in the range between 0.50 and 0.63 indicates a weak oxidizing condition. However, a $\mathrm{Cu} / \mathrm{Zn}>0.63$ indicates an oxidizing condition. And, it has been concluded that the higher the content of $\mathrm{FeO}$ in the stratum was, the stronger the reducibility of the sedimentary environments would be (Deng and Qian 1993). The geochemical parameters of $\mathrm{Cu} / \mathrm{Zn}, \mathrm{V} /(\mathrm{V}+\mathrm{Ni})$, and $\mathrm{Ni} / \mathrm{Co}$ ratio reflected the fact that the Oil 2-Coal 1-Oil 
Table 3 Key major element data of coal and oil shale symbiotic assemblage of the Huangxian Basin

\begin{tabular}{lrrllllllllll}
\hline No. & $\mathrm{SiO}_{2}, \%$ & $\mathrm{Al}_{2} \mathrm{O}_{3}, \%$ & $\mathrm{Fe}_{2} \mathrm{O}_{3}, \%$ & $\mathrm{MgO}, \%$ & $\mathrm{CaO}, \%$ & $\mathrm{Na}_{2} \mathrm{O}, \%$ & $\mathrm{~K}_{2} \mathrm{O}, \%$ & $\mathrm{MnO}, \%$ & $\mathrm{TiO}_{2}, \%$ & $\mathrm{P}_{2} \mathrm{O}_{5}, \%$ & $\mathrm{FeO}, \%$ & $\mathrm{LOI}, \%$ \\
\hline BZ10 & 44.600 & 11.470 & 5.060 & 1.830 & 6.200 & 2.060 & 1.700 & 0.093 & 0.541 & 0.199 & 3.690 & 25.66 \\
$\mathrm{BZ9}$ & 4.350 & 0.325 & 0.223 & 0.147 & 0.358 & 0.593 & 0.035 & $<0.004$ & 0.034 & 0.007 & 0.110 & 93.41 \\
$\mathrm{BZ8}$ & 3.250 & 0.563 & 0.232 & 0.162 & 0.295 & 0.593 & 0.059 & $<0.004$ & 0.036 & 0.009 & 0.120 & 94.65 \\
$\mathrm{BZ7}$ & 5.540 & 0.957 & 0.235 & 0.200 & 0.290 & 0.641 & 0.116 & $<0.004$ & 0.046 & 0.100 & 0.130 & 91.59 \\
$\mathrm{BZ6}$ & 17.580 & 2.600 & 1.110 & 0.262 & 1.470 & 1.500 & 0.183 & 0.034 & 0.075 & 0.114 & 0.670 & 74.54 \\
$\mathrm{BZ5}$ & 38.310 & 2.210 & 2.150 & 0.443 & 6.650 & 0.657 & 0.268 & 0.083 & 0.099 & 0.257 & 1.290 & 47.22 \\
$\mathrm{BZ4}$ & 30.460 & 3.990 & 5.310 & 0.682 & 16.04 & 1.050 & 0.610 & 0.142 & 0.173 & 0.354 & 2.520 & 36.84 \\
$\mathrm{BZ3}$ & 21.090 & 1.840 & 0.951 & 0.264 & 0.934 & 0.683 & 0.215 & 0.013 & 0.070 & 0.152 & 0.830 & 73.67 \\
$\mathrm{BZ2}$ & 40.520 & 6.370 & 3.250 & 1.030 & 9.760 & 1.150 & 0.707 & 0.086 & 0.264 & 0.242 & 1.540 & 64.92 \\
$\mathrm{BZ1}$ & 35.760 & 6.910 & 6.040 & 1.550 & 10.060 & 1.340 & 0.826 & 0.147 & 0.281 & 0.459 & 3.560 & 33.58 \\
\hline
\end{tabular}

Test unit: Nuclear Industry Geological Testing and Research Center. Note: LOI—loss on ignition

1 symbiotic assemblage had basically all developed in weak oxidation and weak reduction environments. The $\mathrm{Cr}$ and $\mathrm{Ni}$ elements reflected that the reducibility of the oil shale formation environments was generally stronger than that of the coal formation environment. Also, at the lower part of the oil shale member, the reducibility had been weakened with the evolution of the sedimentary environment and had reached a minimum level during the coal-forming period. The reducibility of the water mass indicated a regularity in the gradual decreases following a sudden enhancement.

\subsubsection{Paleoclimate and water salinity characteristics of the coal and oil shale symbiotic assemblages}

The paleoclimate and water salinity are important geological parameters of the coal and oil shale genetic environments, and many of these geochemical parameters are known to indicate the paleoclimates and water salinity of various sedimentary periods. In the Oligocene Oil 2-Coal 1-Oil 1 symbiotic assemblage, the evolution of $\mathrm{MgO}$ content and $\mathrm{Sr} / \mathrm{Cu}$, $\mathrm{CaO} / \mathrm{MgO}, \mathrm{Rb} / \mathrm{Sr}$ ratios is relatively consistent in the vertical direction, showing that the $\mathrm{MgO}$ content and $\mathrm{Sr} / \mathrm{Cu}, \mathrm{CaO}$ / $\mathrm{MgO}, \mathrm{Rb} / \mathrm{Sr}$ ratios of oil shale are higher than those of coal seam, and they reach a maximum value in the early stage of development of oil shale and then decrease gradually and reached a minimum value at the coal seam. And the $\mathrm{Sr} / \mathrm{Cu}$ ratio was greater than 10 . The $\mathrm{Sr} / \mathrm{Ba}$ ratio was between 0.12 and 1.02 , and only at the sample point BZ4 was the $\mathrm{Sr} / \mathrm{Ba}$ ratio $>1$ (1.02) (Fig. 6).

We know that the $\mathrm{Sr} / \mathrm{Cu}$ ratio reflects dry or humid climates (Lerman 1989), with a $\mathrm{Sr} / \mathrm{Cu}>10$ reflecting a dry and hot climate and a $\mathrm{Sr} / \mathrm{Cu}<10$ indicating a wet and cold climate (Wang et al. 1997; Xiong and Xiao 2011; Hu et al. 2012; Fan et al. 2012; Xue 2013). Also, high values of the $\mathrm{MgO} / \mathrm{CaO}$ ratio and $\mathrm{MgO}$ content indicate that the climate is dry and hot, and low values reflect humid climates (Xue
2013). When the $\mathrm{Rb} / \mathrm{Sr}$ ratio is low, a warm and humid climate will exist, and increases in the $\mathrm{Rb} / \mathrm{Sr}$ ratio suggest a hot and dry climate (Liu et al. 1984; Jin and Zhang 2002). The $\mathrm{Sr} / \mathrm{Ba}$ ratio is commonly used to reflect the water salinity and its corresponding climatic conditions. For example, high values of the $\mathrm{Sr} / \mathrm{Ba}$ ratio reflect high salinity or a hot arid climate, and low values reflect low salinity or a warm and humid climate. Generally speaking, a $\mathrm{Sr} / \mathrm{Ba}$ ratio $>1$ indicates a marine deposition or lake salinity deposition in an arid climate, and a $\mathrm{Sr} / \mathrm{Ba}$ ratio $<1$ indicates a freshwater deposition (Deng and Qian 1993). In the Oligocene Oil 2-Coal 1-Oil 1 symbiotic assemblage of the Huangxian Basin, the $\mathrm{Sr} / \mathrm{Cu}$ ratio indicates dry climate conditions. As indicated by the $\mathrm{CaO} / \mathrm{MgO}$ and $\mathrm{Rb} / \mathrm{Sr}$ ratios, a relatively dry climate had existed in the symbiotic assemblage during the oil shale development period. Meanwhile, a relatively humid climate was evident during the development period of the coal seam. Moreover, the climate conditions during the oil shale development period were confirmed to be an early sudden massive dry heat, followed by gradual warm humidity conditions. The paleoclimate presented the characteristics of a regularity of gradual warm humidity following sudden dry heat conditions. The $\mathrm{Sr} / \mathrm{Ba}$ ratio of the Oil 2-Coal 1-Oil 1 symbiotic assemblage indicates that the water salinity during the formation period of the oil shale was higher than that of the coal-forming period. Moreover, at the beginning of the oil shale formation period, the water salinity was increased suddenly to reach the level of brackish salt water. This may have been related to a dry hot climate or transgression function (Wang et al. 2000; Xu et al. 2006, 2012; Zhou et al. 2006; Lv et al. 2017), followed by a gradual decrease in the water salinity. The coalforming period was basically dominated by fresh water, and the water salinity showed the regularity of a sudden increase followed by a gradual decrease. 


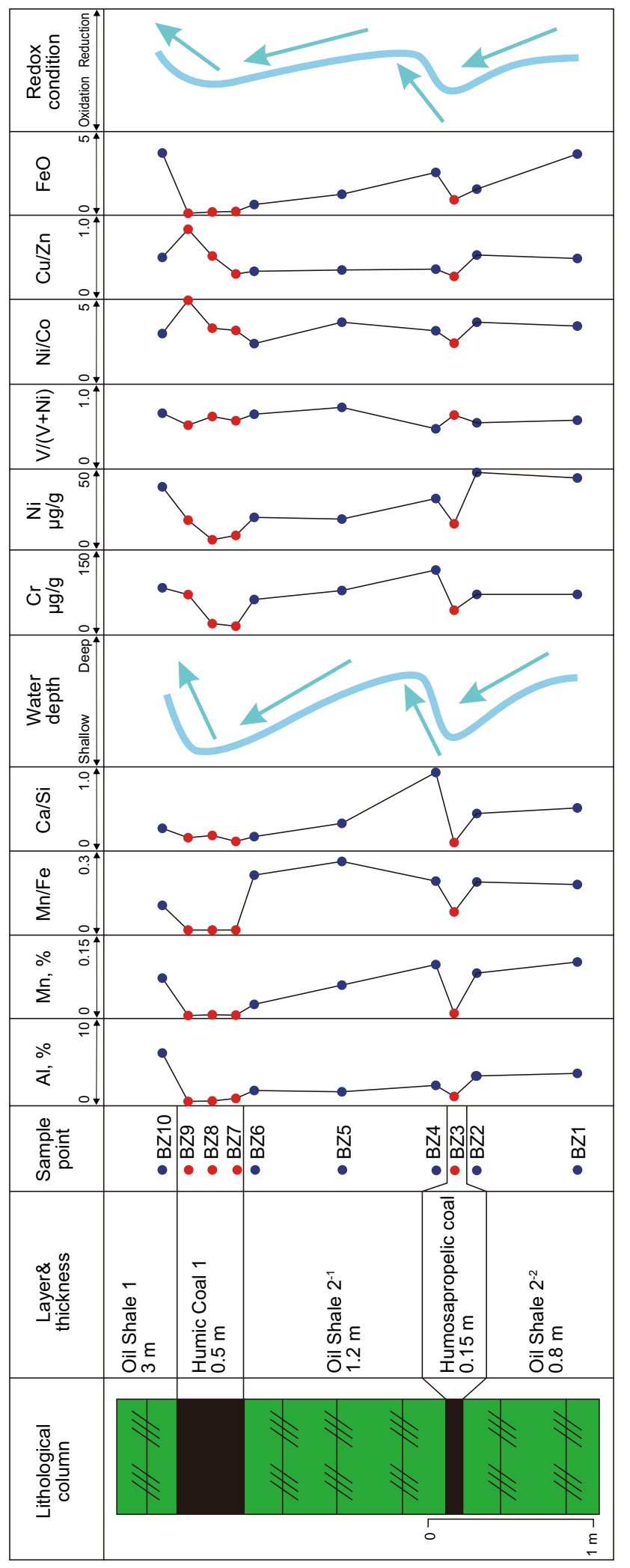

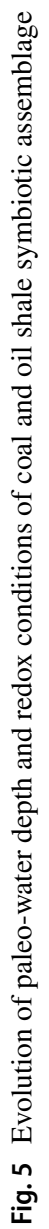




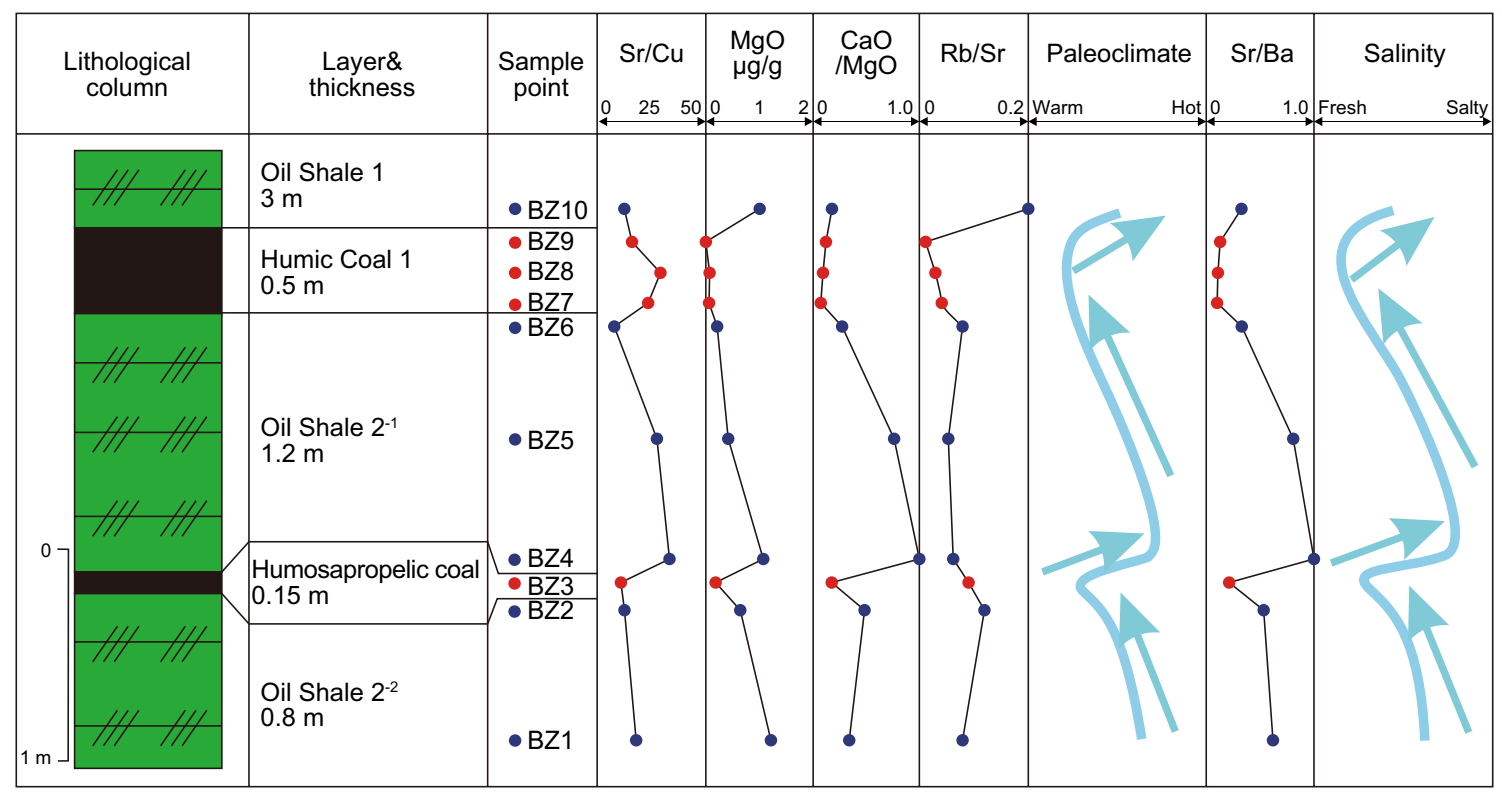

Fig. 6 Evolution of paleoclimate and water salinity of coal and oil shale symbiotic assemblage

\subsection{Rapid transformation mechanism of the coal and oil shale genetic environments}

The development of a paleo-lake basin is controlled by the tectonic subsidence, sediment supply, and climatic conditions, which obviously affect the elevation of the lake's surface. In a continental fault basin, the tectonics are the most important controlling factors of the sediment filling (Feng et al. 2000; Yu et al. 2007), and the formation and evolution of a basin's sedimentary formation are mainly controlled by the tectonic events or episodic tectonic cycles (Wang et al. 2007a, b). Faulting activities directly restrict the accumulation of basin sediment by controlling the basement-lifting movements (Deng et al. 2008). The lacustrine depositional cycle (rhythm) is the indirect response to the basin's tectonic cycles (or fluctuations) (Tao et al. 2007). The different levels of tectonic activities control the multilevel sedimentary characteristics within a basin (Jiao et al. 1996), and the short-cycle episodic tectonic subsidence has obvious control effects on the high-frequency sedimentary cycles of continental fault basins (Ren et al. 2005). When the tectonic subsidence rate is relatively fast, the supply rate of the sediment (including peat) will be somewhat smaller than the increase rate of the accommodation space, which is beneficial to the development of oil shale. However, when the tectonic subsidence is slow, the increase rate of the accommodation space will be roughly balanced by the peat accumulation rate, which is beneficial to the development of coal seams. The fault structures obviously control the development, thickness, and distribution characteristics of both the oil shale and coal deposits. For example, in the
Maoming Basin of Guangdong, the oil shale formation strike is consistent with the tectonic line, and the thicknesses of the coal seam and oil shale are negatively correlated, which is in line with the secondary depression development $(\mathrm{Li}$ et al. 2006). The synsedimentary basement faults in the Fushun Basin control the thickness and distribution of the oil shale, and the complex structure controls the member thicknesses of the coal and oil shale (Liu 2008). As can be seen from the abovementioned examples, the episodic structures of continental fault basins largely control the type, filling, and evolution of the sediment to a great extent. Continental fault basins have smaller areas with small and narrow water masses. The deepwater sediment in small and deep basins usually has high deposition rates and frequency cycles, which leads to major changes in the lacustrine depositional environment from freshwater to saltwater and from shallow water to deepwater. This results in the formations of oil shale, evaporite, peat bog, coal, and other sediments $(\mathrm{Hu}$ and Peng 2017).

The Earth's cold/warm and dry/wet climates are closely related to the carbon cycle. Chen et al. (2018) found that the continental weathering and organic carbon which was buried underground (to form coal deposits) had led to the emergence of the Late Paleozoic Great Ice Age. The underground burial of organic carbon (coal formations) reduced the temperature of the atmosphere during that period to a certain extent. When the coal seams were formed, a large amount of organic carbon was buried underground, which led to decreases in temperature. After the completion of water depth changes and other factors resulting from the coal formation, the climate became dry once again. These 
higher temperatures were conducive to the development of algal blooming, which was beneficial to the development of oil shale.

Through the above analyses, it could be seen that the development of coal and oil shale deposits in the continental fault basins was impacted by the tectonic and climate conditions to a great degree. The tectonic and climate conditions jointly led to the transformations of the coal and oil shale genetic environments. The overall relatively dry and hot climate was beneficial to algae blooming, which produced large amounts of organic matter. Then, following a rapid tectonic subsidence, the water masses were rapidly deepened, which led to water stratification (transgression also contributed in the offshore basins) and water reducing enhancement, which was conducive to the preservation of the organic matter (such as algae) required for the development of oil shale. Subsequently, the tectonics entered a slow subsidence stable period during which the sediment continuously accumulated, and the water masses gradually became shallower. These conditions were conducive to the flourishing of higher plants and the further development of peat bogs. Due to the accumulation of peat and the formation of coal, with large amounts of organic carbon becoming buried underground, the climate gradually became warm and humid. Also, the water salinity decreased, which was conducive to the growth of peat swamps and the formation of peat (coal). During the next stage of the rapid settlement, the water masses deepened once again, and the peat bogs were submerged. The coal-forming action was terminated at the stage, which caused the temperature to rise again. These conditions were conducive to the production of algae and organic matter. The deepening of the water masses was beneficial to the formation of water stratification (transgression also contributed in the offshore basins) and relative reducing conditions and was favorable to the preservation of such organic matter as algae. The results were the formation of oil shale during this period. The abovementioned processes appeared during the various assemblage formations, which resulted in different types of coal and oil shale symbiotic assemblages.

From the viewpoint of the coal and oil shale organic matter compositions, the organic matter in coal mainly consisted of higher plants and much less algae, and the organic matter in oil shale was dominated by algae and terrestrial higher plants. Algae blooms had appeared during the entire sedimentary period of the oil shale. In the early sedimentary period of the oil shale, rapid tectonic subsidence and sudden significant water-deepening conditions had led to the lacustrine organic matter being in short supply, which indicated a relatively low lake productivity. Subsequently, the tectonic subsidence gradually slowed down, and the supply of the lake organic matter gradually became sufficient once again, presenting a gradually rising productivity of the lake. During the coal formation phase, the terrigenous higher plants flourished, and the lake productivity reached its lowest. At this time, the area entered a peat bog environment stage, during which coal seams with extremely rich organic matter were formed.
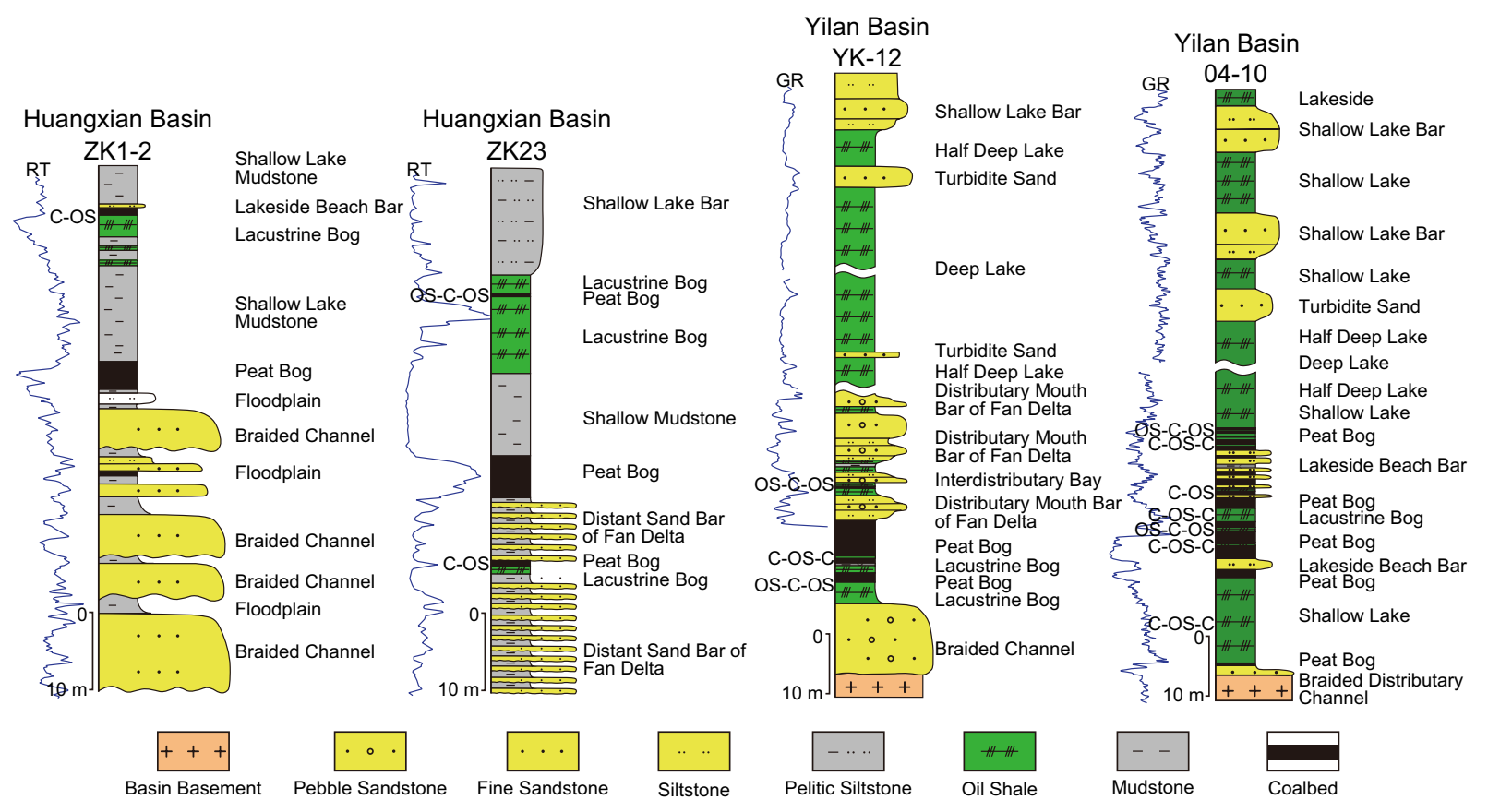

Fig. 7 Typical sedimentary sequence of coal and oil shale symbiotic assemblage in continental fault basins 
In summary, the transformations of the genetic environments of the coal and oil shale symbiotic assemblages in continental fault basins were determined to have been mainly controlled by the tectonic activities and climate evolution of the area.

\subsection{Sedimentary process of the coal and oil shale symbiotic assemblages}

In essence, the sedimentary processes of the different types of coal and oil shale symbiotic assemblages refer to the oil shale environments becoming transformed into coal formation environments and the coal formation environments becoming transformed into oil shale formation environments (Wang et al. 2016; Li et al. 2016). The other symbiotic assemblages were different forms of these two main types.

1. Transformations of the coal-oil shale (C-OS) genetic environments

When the oil shale deposits form the direct roofs of coal seams (Fig. 7), these assemblages have generally developed during the early-middle period of a basin's evolution. During the development period of peat bogs, the lakesidelimnetic environments in which the water levels are relatively shallow are where the peat becomes accumulated and eventually forms into coal. Due to the active tectonics of fault basins, sudden tectonic sedimentation caused the water masses to deepen rapidly into the limnetic-shallow lake environments. Then, the peat bogs became submerged under deeper water. The deepening of the water masses blocked the injection of terrigenous detrital material, which then led to the enhancement of the water reducibility. Under these climate or transgression actions, water stratification occurred, and combined with seasonal algae blooming, provided abundant organic matter. These conditions were beneficial to the development of oil shale. If the tectonics continued to settle, the water masses continued to deepen, and the area entered into a shallow lake or even deep lake environmental phase. During this period, oil shale with a great thickness may have been developed, rather than the coal seams.

2. Transformations of the oil shale-coal (OS-C) genetic environments

When the oil shale deposits form the direct floors of the coal seams (Fig. 7), these assemblages have generally developed during the mid-late stages of a basin's evolution. The oil shale deposits are mainly developed in lakeside-shallow lake and even deep lake environments. During the sedimentary periods of oil shale development, the tectonics were stable; the lakes were deep with stable stratification, and seasonal algae blooming occurred with a full supply of organic matter. As the sediment continued to accumulate, the water masses gradually became shallower until the area became a swamp environment. Then, under these favorable environmental conditions, peat accumulated in the swamp to eventually form coal seams.

In addition to the aforementioned two main assemblage types, there were also coal-oil shale-coal assemblages; oil shale-coal-oil shale assemblages; coal-other sediment-oil shale assemblages; and other assemblages. The emergence of these assemblages was the products from the mutual transformations of the coal and oil shale formation environments in accordance with the different assemblage forms. These types have long sedimentary time periods and large thicknesses. In the cases of active tectonics, multiple assemblages frequently appeared and terminated, which had led to relatively small bed thicknesses in the various assemblages appearing multiple times. During the relatively slow tectonic periods, few types of symbiotic assemblages were apparent, and the various beds exhibited greater thicknesses, or even ultra-thick layers.

\section{Sequence stratigraphic characteristics of the coal and oil shale symbiotic formations}

\subsection{Key sequence stratigraphic interfaces of the coal and oil shale symbiotic formations}

Sequence stratigraphy is an important method used to study the development and occurrence of sedimentary deposits. The sequence stratigraphy interfaces of the coal and oil shale symbiotic formations in continental fault basins display similarities to other continental fault basins. The main types of existing sequence interfaces (Catuneanu et al. 2009) include the following: (1) tectonic movement interface-regional unconformity surfaces; (2) paleo-weathering exposure surfaces, including paleo-soil and seat rock; (3) river rejuvenation and riverbed retention sediment bottom interfaces; (4) conversion surfaces of sedimentary features; (5) surfaces of biomasses and populations; and (6) geochemical signs, such as the discontinuity surfaces of trace element content $(\mathrm{Wu}$ et al. 1998a, b).

In continental lake sequence stratigraphy analyses, oil shale deposits are often seen as the condensation member of a sequence and are known to represent the deepest water levels and finest grained under-filling depositions (Wei and Xu 1994; Wang and Liu 1994). For example, the transitional position between the bottom of an extremely thick oil shale member and coal seam in the Dalianhe Formation of the Yilan Basin represents the sedimentation which occurred in the condensation member during a maximum flooding period (Liu 2007a, b). In the condensation member, the 
$\delta^{13} \mathrm{C}$ was characterized by a low peak, which may have been related to the rich ${ }^{12} \mathrm{C}$ levels and high organic carbon content in the condensation member. These findings reflected a rise in sea level (Yu 1995) during this period in which the condensation member of the Dalianhe Formation of the Yilan Basin was characterized by a low level of $\delta^{13} \mathrm{C}$ (Liu 2007a).

However, the oil shale layers are not always the condensation members, especially in the strata containing many oil shale layers. If the oil shale layers are the turning points of the accommodation spaces in which increases changed to decreases (the turning points of the retrogradation, accretion, or progradation) within a sequence, then the bottom boundary of the oil shale layers represents a maximum flooding surface. However, if other condensation members with greater thicknesses (such as black shale and so on) are evident within a sequence above the oil shale layers, then the oil shale layers only represent a major flooding surface, rather than a maximum flooding surface or distinguishing of a system tract (Liu and Wang 1996).

\subsection{Sequence stratigraphic framework division of the coal and oil shale symbiotic formations}

In combination with the sedimentary filling characteristics of continental fault basins, this study selected a quartering division scheme of a continental fault lake basin sequence. Similar to the previous sequence quartering schemes (Zhang and Ji 1996; Dong et al. 2003; Catuneanu et al. 2009; Liu et al. 2002, 2013), the sequence of the coal and oil shale symbiotic development members in a continental fault basin was divided into a low stand system tract (LST); lake expansion system tract (EST); early high stand system tract (EHST); and late high stand system tract (LHST). Then, in the sequence stratigraphic units, an accretion, retrogradation, and two aggradation quasi-sequence groups were formed. Within the different quasi-sequence groups, the symbiotic assemblage presented regular development and occurrence characteristics.

When examining paleo-lakes, Bohacs et al. (2000) determined that oil shale deposits are prone to accumulate in the lake expansion system tract, as well as in the early high stand system tract. Also, it was observed that coal seams were most likely to appear in lake expansion system and early high stand system tracts (Li et al. 1996; Shao et al. 2009).

\subsection{Symbiotic development characteristics of coal and oil shale in different system tracts}

The results of the stratigraphic sequence analyses of the coal and oil shale symbiotic development characteristics in coalbearing basins revealed that the development characteristics and their symbiotic assemblages were different in the various system tracts as detailed below:
(1) Low stand system tracts (LST)

During this period, the oil shale or coal seams with relatively small developmental thicknesses and limited distribution ranges were generally developed. However, there was very little development of the coal and oil shale symbiotic assemblages (Figs. 7,8 ). In some of the local areas, the tectonic subsidence was relatively quick during the low stand period, where the coal and oil shale symbiotic assemblages with small development scales were also able to develop. For example, in the 4-10-hole low stand system tract of the Yilan Basin, the coal/oil shale/coal assemblage had developed. In that particular location, the thickness of lower coal seam was found to be minimal $(0.49 \mathrm{~m})$. Meanwhile, the thickness of the oil shale was larger $(14.36 \mathrm{~m})$, and the thickness of the upper coal seam was also larger than the lower seam $(1.18 \mathrm{~m})$, as detailed in Fig. 8. During this period, the water level was low and water surface was stable. Also, the accommodation space had been slowly produced, which was not conducive to the development of coal. The sites with relatively deepwater masses were beneficial to water stratification, and a certain thickness of oil shale developed under the lake's own productivity, along with a good supply of terrigenous detrital plants.

\section{(2) Lake expansion system tracts (EST)}

During this period, various coal and oil shale symbiotic assemblages had developed, in which the thicknesses of coal seams and oil shale deposits were relatively small, with multiple layers and wide distribution ranges (Figs. 8, 9), such as the Eocene Dalianhe Formation of the Yilan Basin (Wang et al. 2013a, b, 2016) (Fig. 8) and the Oligocene Lijiaya Formation of the Huangxian Basin (Lv et al. 2017). Also, during this period, the tectonic movements of episodic activities had led to periodical occurrences of lake flooding. The tectonic movements caused lake flooding and resulted in the lake levels rising rapidly. The water masses became deeper at increased rates, and the accommodation space also increased rapidly. The terrigenous debris injection was restricted in the lakeside area with the insufficient supply of fragmental material, and the accommodation space's increase rate and sediment supply rate increased rapidly. Certain water depths are known to be conducive to stable water stratification, and when combined with seasonal algae blooming, provide conditions which are favorable for the development of oil shale. At the end of the lake flooding period, the water masses gradually became shallower, and the lake periphery evolved into a lakeside peat bog, where higher plants thrived and the A/S ratio decreased quickly. The peat layer accumulated on the upper part of the oil shale and eventually evolved into coal seams, or in other words, an $\mathrm{OS}-\mathrm{C}$ assemblage was formed. If the peat bog continued 


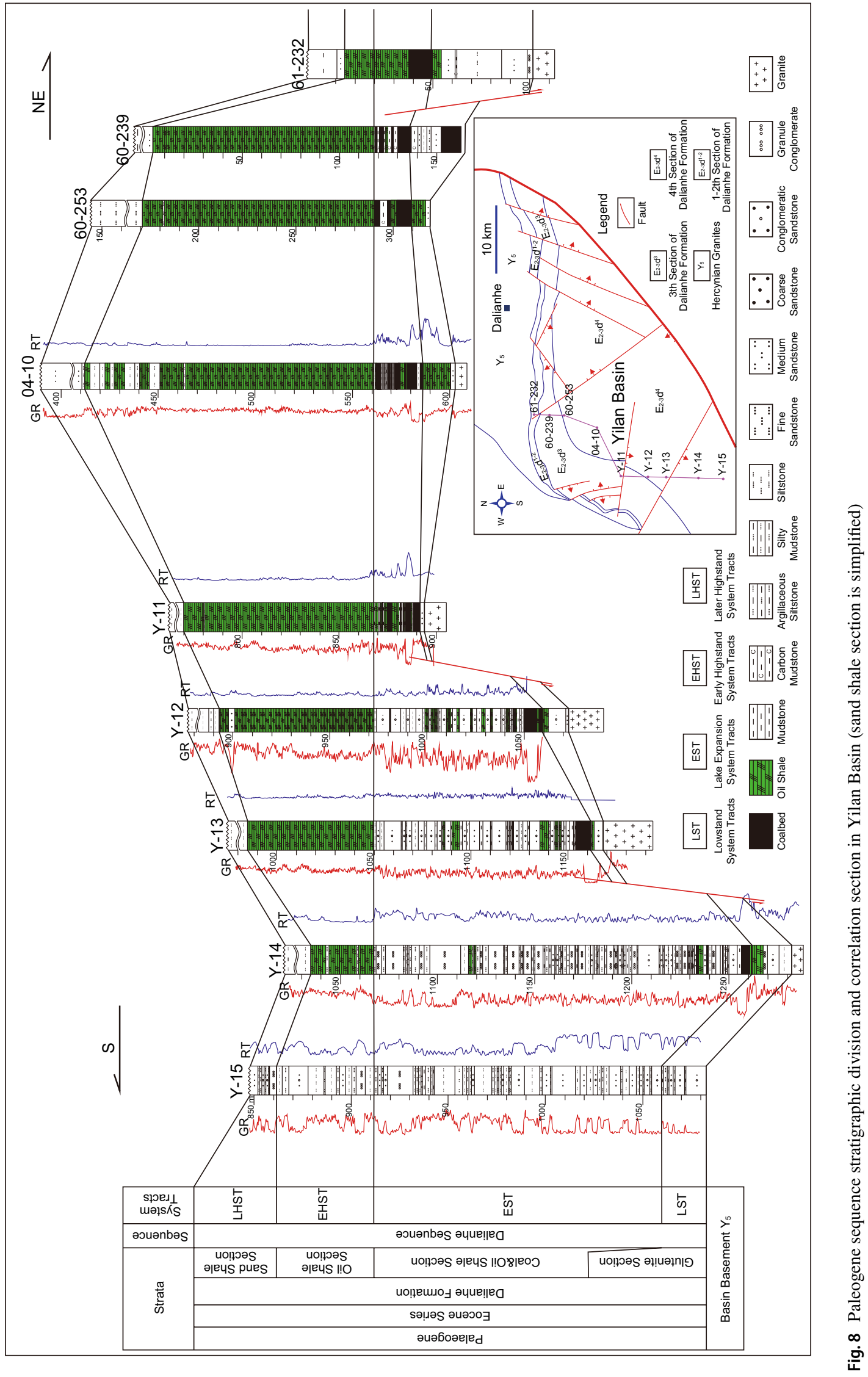


Fig. 9 Base level change characteristics of typical coal and oil shale symbiotic assemblages

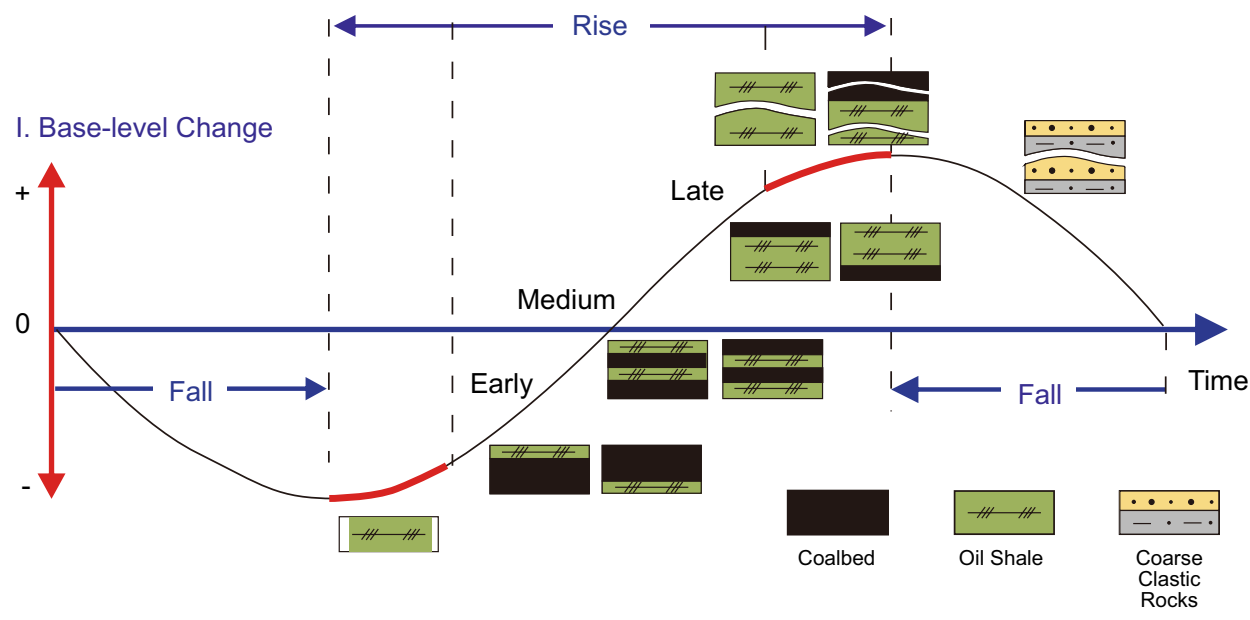

II. Rates of Base-level Change

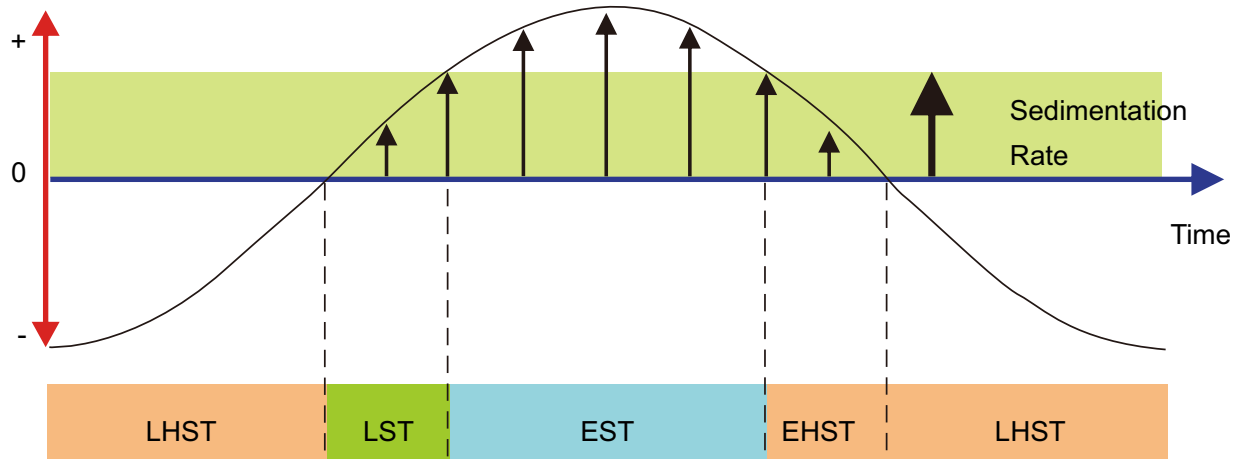

to develop into the next phase of lake flooding, then the oil shale would become deposited on top of the peat layer and would eventually evolve into an OS-C-OS assemblage. During the development processes of lakeside peat bogs, tectonic movements had occurred which caused lake flooding. The lake level rose rapidly, and the accommodation space increased at a faster rate. The peat accumulation quickly transitioned into oil shale sediment, and a C-OS assemblage developed. At the end of the lake flooding period, the water masses gradually became shallower, and lakeside peat bogs developed once again. The peat accumulated again on the upper oil shale and eventually evolved into a C-OS-C assemblage. It was determined that when the development of the coal and oil shale had been two independent processes, the phenomenon of the other lithologic deposits between the coal and oil shale deposits was more common. For example, $\mathrm{C}-\mathrm{M} / \mathrm{S}-\mathrm{OS}$ assemblages were evident.

During this period, the peripheral areas of the lake were less affected by lake flooding and the water remained shallow. Therefore, the formation of oil shale generally did not occur in these areas. In the middle section of the lake, peat bogs had generally not developed in the sites with deeper water at the end of lake flooding, and coal seams could not be formed. The coal and oil shale symbiotic assemblages had difficulty developing in the lake's peripheral sites.

\section{(3) Early high stand system tracts (EHST)}

During this period, the OS-C symbiotic assemblages were often developed with greater thicknesses (Figs. 8, 9), such as the Eocene Dalianhe Formation of the Yilan Basin (Wang et al. 2013a, b, 2016) and Eocene Fushun Basin (Liu 2007a). The lake plain and shoreline of the basin were relatively stable during this period, as was the supply of terrigenous detrital materials. Also, the A/S ratio experienced few changes. The water depth was greater in the lake, and terrigenous debris injection only affected the lakeside areas. Moreover, the greater water depth was prone to relatively stable water stratification. The warm moist paleoclimate was conducive to seasonal algae blooming and a plentiful terrigenous detrital plant supply. During this period, the oil shale deposits were prone to develop with greater thicknesses in the lake and then gradually thinned and pinched toward the lakeside. The coastal areas of the lake were conducive to the development of peat bogs. A thick layer of coal had formed, with gradual thinning and pinching toward the coal seams located in the middle of the lake. With the continuous filling 


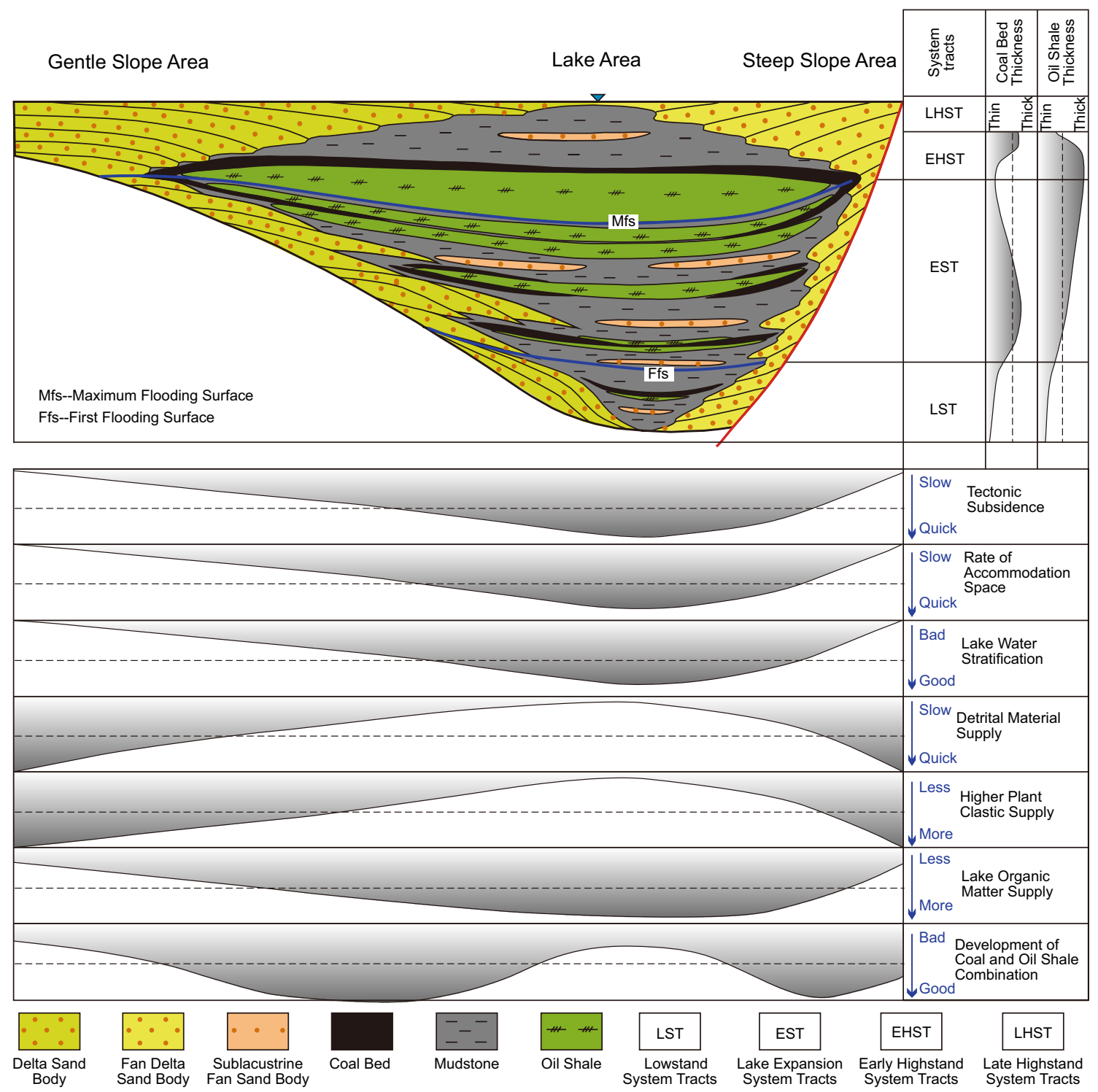

Fig. 10 Coal and oil shale coexisting model of the sequence stratigraphic framework in a continental rift basin

of lake from terrigenous detrital materials, the peat bogs also migrated toward the lake's center, and the peat continued to accumulate on the upper oil shale, resulting in the development of an OS-C assemblage (Fig. 9). It was determined that under suitable conditions, this type of assemblage could be found throughout almost the entire lake. Also, this type of symbiotic assemblage was generally stable and characterized by greater bed thicknesses.

\section{(4) Late high stand system tracts (LHST)}

During this period, coal and oil shale symbiotic assemblages (Figs. 8,9 ) rarely developed. The lake areas had largely vanished during this period, and various delta or river sediments were mainly developed. Therefore, with the higher terrigenous detrital material input, some peat bogs did develop during this period and eventually evolved into coal seams. However, the development conditions of the oil shale were not evident, such as a certain depth of water and water stratification, and coal and oil shale symbiotic assemblages were rare.

\subsection{Coal and oil shale symbiotic development model under a sequence stratigraphic framework}

The symbiotic development of coal and oil shale is influenced by many geological conditions, such as tectonic activities, climatic conditions, water stratification, injection of terrigenous detrital material, and organic matter supplies. 
The combined actions of many factors have led to the occurrences of different coal and oil shale multi-assemblage styles and developmental regularities. Under the sequence stratigraphic framework of continental fault basins, coal and oil shale symbiotic assemblages have been mainly developed in lake expansion and early high stand system tracts. It has been observed that in different system tracts, various types of coal and oil shale symbiotic assemblages have developed with diversified characteristics (Fig. 10).

The lake expansion system tract type is known to be the most favorable for the development of coal and oil shale symbiotic assemblages. Five types of coal and oil shale symbiotic assemblages have been identified in this type of system tract. During the deposition process of a lake expansion system tract, the accommodation space changed quickly, and lake expansion had multiple phase and transient characteristics which led to the coal and oil shale deposits becoming featured by multiple layers and small thicknesses. During the early and later stages of a lake expansion system tract, the change rates of the accommodation space were much slower. Therefore, during the early stage of a lake expansion system tract, the water masses were relatively shallow and prone to vertically thin layers of oil shale and thick-layered coal assemblages. However, during the middle stage, the water depths were moderate and prone to coal and oil shale assemblages with equivalent thicknesses. During the later stage, the water masses were again relatively deep, and thinlayered coal seams with thick-layered oil shale assemblages were evident. In other words, from the early to later stages of a lake expansion system tract, the thicknesses of the coal seams gradually decreased, while the thicknesses of the oil shale deposits gradually increased (Wang et al. 2016). The coal and oil shale symbiotic assemblages mainly appeared in the sites with appropriate water depths and rapid frequent conversions (Figs. 8, 10). Excessively deepwater was not conducive to the growth of peat bogs, and excessively shallow water was not beneficial to the development of oil shale. If the water depths were not quickly converted, other sedimentary types were commonly found between the coal and oil shale deposits. From the lakeside to the lake center, there was no specific regularity observed in the development of the different types of symbiotic assemblages. This was determined to be related to the tectonic development and activities. However, in terms of a certain symbiotic assemblage from the lakeside to the lake center, it was observed that the thicknesses of the coal seams had gradually thinned and finally became bifurcated and pinched. In contrast, the oil shale deposits were not very developed in the lakeside areas, and the thicknesses were found to have gradually increased toward the lake center. In continental fault basins, the phenomenon of coal and oil shale phase changes has not been observed. In addition, coal and oil shale symbiotic assemblages are common at sites with lower supplies of terrigenous detrital material. A large supply of terrigenous detrital material tends to the formation of stable lake water stratification destruction and results in conditions which hinder oil shale development. Therefore, the sites and periods with lower terrigenous clastic supply were more conducive to the development of coal and oil shale symbiotic assemblages. These were often characterized by the upper and lower rock in the symbiotic assemblages mainly consisting of fine-grained sediment such as mudstone. This was found to be evident in the Lijiaya Formation of the Huangxian Basin. In special cases, oil shale deposits can also be directly exposed to coarse clastic deposits, such as in the Dalianhe Formation of the Yilan Basin (Figs. 8, 10).

During the early stages of a high stand system tract, the sedimentary environment was stable and characterized by deep lake water levels. In the lake's central areas, oil shale layers with maximum thicknesses in the sequence were often developed. Then, the oil shale exhibited thinning and pinching trends toward the lakeside areas. In the lakeside plain areas, coal seams with maximum thicknesses in the sequence had developed and were characterized by gradual thinning and pinching toward the lake center. However, with the constant input of terrigenous detrital material into the lake, the peat bogs also migrated toward the lake center. The peat layers accumulated above the oil shale sediment and eventually developed into OS-C assemblages with maximum thicknesses and good stability.

The low stand system tract and the late high stand system tract were not conducive to the development of coal and oil shale symbiotic assemblages and were not described in this study.

\section{Conclusions}

Using the results of a massive number of surveys which had been previously completed regarding the development of coal and oil shale symbiotic assemblages in China and internationally, particularly the detailed research conducted on the coal and oil shale symbiotic assemblages in the Cenozoic continental fault basins of eastern China, systematical experimental testing and isochronous sequence stratigraphy studies were conducted. The following conclusions were subsequently obtained:

1. Although the genetic environments of coal and oil shale are different, they also have similarities, which provide the possibility for the transformation of their genetic environment.

2. In the symbiotic assemblages, the transformations of coal and oil shale genetic environments were mainly controlled by the tectonism and climate conditions of the areas. Tectonic activity leads to the abrupt change of 
the genetic environment, which induces the development of oil shale, and then the genetic environment enters a stable gradual stage and finally transforms into the coalforming environment.

3. Within the sequence stratigraphic framework, the development characteristics of the coal and oil shale symbiotic assemblages in the various system tracts were different. In general, the lake expansion system tract (EST) was determined to be the most beneficial to the growth of the various symbiotic assemblages. The early stages of the high stand system tract (EHST) were beneficial to the symbiotic assemblages of a thick coal seam overlying the thick oil shale deposit. The low stand system tract (LST) and the late high stand system tract (LHST) were determined to be unconducive for the development of the symbiotic assemblages.

Acknowledgements This work was supported by the National Key Research and Development Plan (2017YFC0601400), SDUST Research Fund (2018TDJH101), and the National Natural Science Foundation of China (41402086, 272172).

\section{Compliance with ethical standards}

Conflict of interest The author(s) declared no potential conflicts of interest with respect to the research, authorship, and/or publication of this article.

Open Access This article is distributed under the terms of the Creative Commons Attribution 4.0 International License (http://creativeco mmons.org/licenses/by/4.0/), which permits unrestricted use, distribution, and reproduction in any medium, provided you give appropriate credit to the original author(s) and the source, provide a link to the Creative Commons license, and indicate if changes were made.

\section{References}

Ahmed W. Sedimentology, depositional environments and basin evolution of coal and oil shale-bearing sediments in the DelbiMoye Basin, Southwestern Ethiopia. SINET Ethiop J Sci. 2004;27(1):45-60. https://doi.org/10.4314/sinet.v27i1.18221.

Bai WH, Wu YB, Gao ZL, et al. Study of the mechanism of oil shale enrichment in a shallow to half-deep lake depositional environment. Geol Surv Res. 2010;33(3):207-14 (in Chinese).

Bechtel A, Jia JL, Susanne AIS, et al. Palaeoenvironmental conditions during deposition of the Upper Cretaceous oil shale sequences in the SongliaoBasin (NE China): implications from geochemical analysis. Org Geochem. 2012;46:76-95. https://doi. org/10.1016/j.orggeochem.2012.02.003.

Bohacs KM, Carroll AR, Neal JE, et al. Lake-basin type, source potential, and hydrocarbon character: an integrated sequence-stratigraphic-geochemical framework. In: Gierlowski-Kordesch EH, Kelts KR, editors. Lake basins through space and time., AAPG studies in GeologyTulsa: AAPG; 2000. p. 3-33.

Boyer BW. Green river laminites: Does the playa-lake model really invalidate the stratified-lake model. Geology. 1982;10:321-4. https://doi.org/10.1130/0091-7613(1982)10321:grldtp2.0.co;2.
Bradley WH, Eugster HP. Geochemistry and paleolimnology of the trona deposits and associated authigenic minerals of the green river formation of Wyoming. US Geol Surv Prof Pap. 1969;803:51-3. https://doi.org/10.1007/BF00183071.

Cameron AR, Goodarzi F, Potter J. Coal and oil shale of Early Carboniferous age in northern Canada: significance for paleoenvironmental and paleoclimatic interpretations. Palaeogeogr Palaeoclimatol Palaeoecol. 1994;106(1-4):135-55. https://doi. org/10.1016/0031-0182(94)90007-8.

Catuneanu O, Abreu V, Bhattacharya JP, et al. Towards the standardization of sequence stratigraphy. Earth-Sci Rev. 2009;92:1-33. https ://doi.org/10.1016/j.earscirev.2008.12.003.

Chen GD. Introduction to Chinese oil shale. Geol Rev. 1951;2:109-36. https://doi.org/10.16509/j.georeview.1951.02.021 (in Chinese).

Chen JT, Montañez IP, Qi Y, et al. Strontium and carbon isotopic evidence for decoupling of $\mathrm{pCO} 2$ from continental weathering at the apex of the late Paleozoic glaciation. Geology. 2018;46(5):3958. https://doi.org/10.1130/g40093.1.

Chu GQ, Liu JL, Liu DS. Identification and significance of two sedimentary veins in maar lake, China. Chin Sci Bullet. 2000;45(14):1553-7 (in Chinese).

Curiale JA, Gibling MR. Productivity control on oil shale formationMae Sot Basin, Thailand. Org Geochem. 1994;21(1):67-89. https ://doi.org/10.1016/0146-6380(94)90088-4.

Deng HW, Qian K. Sedimentary geochemistry and environmental analysis. Lanzhou: Gansu Science and Technology Press; 1993. p. 1-154 (in Chinese).

Deng HW, Guo JY, Wang RJ, et al. Tectono-sequence stratigraphic analysis in continental faulted basins. Earth Sci Front (China Univ Geosci Beijing Peking Univ). 2008;15(2):1-7. https://doi. org/10.1016/s1872-5791(08)60024-x (in Chinese).

Desborough GA. A biogenic-chemical stratified lake model for the origin of oil shale of the Green River Formation: an alternative to the playa-lake model. Geol Soc of Am Bull. 1978;89:96171. https://doi.org/10.1130/0016-7606(1978)89961:ABSLM $\mathrm{F} 2.0 . \mathrm{CO} ; 2$.

Diessel CFK. Coal-bearing depositional systems. Berlin: Springer; 1992. p. 1-679. https://doi.org/10.1007/978-3-642-75668-9.

Diessel CFK, Boyda R, Wadsworth J, et al. On balanced and unbalanced accommodation/peat accumulation ratios in the Cretaceous coals from Gates Formation, Western Canada, and their sequence-stratigraphic significance. Int J Coal Geol. 2000;43(14):143-86. https://doi.org/10.1016/S0166-5162(99)00058-0.

Dong QS, Liu ZJ, Fang S, et al. On the feasibility of the four division scheme about continental sequence stratigraphy. Acta Sedimentol Sin. 2003;21(2):324-8. https://doi.org/10.14027/j.cnki. cjxb.2003.02.021 (in Chinese)

Eugster HP, Surdam RC. Depositional environment of the Green River Formation of Wyoming: a preliminary report. Geol Soc of Am Bull. 1973;84:1115-20. https://doi. org/10.1130/0016-7606(1973)842.0.co;2.

Fan YH, Qu HJ, Wang H, et al. The application of trace elements analysis to identifying sedimentary media environment: a case study of Late Triassic strata in the middle part of the western Ordos Basin. Geol China. 2012;39(2):382-92. https://doi.org/10.1016/j. still.2012.05.017 (in Chinese).

Feng YL, Li ST, Xie XN. Dynamics of sequence generation and sequence stratigraphic model in continental rift- subsidence basin. Earth Sci Front. 2000;7(3):119-29. https://doi. org/10.3321/j.issn:1005-2321.2000.03.013 (in Chinese).

Feng TT, Li ZX, Lv DW, et al. Symbiotic sedimentary environment and sequence evolution of coal and oil shale in the Jinbaotun mining area in Inner Mongolia. China Coal. 2015;41(2):30-6. https ://doi.org/10.3969/j.issn.1006-530x.2015.02.007 (in Chinese).

Hatch JR, Leventhal JS. Relationship between inferred redox potential of the depositional environment and geochemistry of the 
Upper Pennsylvanian(Missourian) Stark Shale Member of the Dennis Limestone, Wabaunsee County, Kansas USA. Chem Geol. 1992;99(1-3):65-82. https://doi.org/10.1016/00092541(92)90031-y.

Hay ME. Specialist herbivores reduce their susceptibility to predation by feeding on the chemically defended seaweed Avrainvillea longicaulis. Limnol Oceanogr. 1990;35(8):1734-43. https://doi.org /10.4319/10.1990.35.8.1734.

Hecky RE, Fee EJ. Primary production and rates of algal growth in lake Tanganyika. Limnol Oceanogr. 1981;26(3):532-47. https://doi. org/10.4319/lo.1981.26.3.0532.

Hu JF, Peng PA. An overview and perspectives on organic geochemistry. Acta Sedimentol Sin. 2017;35(5):968-81. https://doi. org/10.14027/j.cnki.cjxb.2017.05.009 (in Chinese).

$\mathrm{Hu}$ XF, Liu ZJ, Liu R, et al. Trace element characteristics of the Eocene Jijuntun Formation and the favorable metallogenic conditions for oil shale in the Fushun Basin. J Jilin Univ (Earth Sci Ed). 2012;42(S1):60-71. https://doi.org/10.13278/j.cnki.jjuese.2012. s1.008 (in Chinese).

Jia JL. Research into the recognition and resource evaluation of the Upper Cretaceous oil shale based on geochemistry—geophysics techniques in the Songliao Basin (NE, China). PhD thesis, Jilin University, Jilin, China, 2012;1-176 (in Chinese).

Jiao YQ, Zhou HM, Liu SF, et al. Multistage episodic rifting and its controls on filling in rift basins: taking the Eogene Nanpu Rift Basin as an example. Earth Sci J China Univ Geosci. 1996;21(6):633-5 (in Chinese).

Jin ZD, Zhang EL. Paleoclimate implications of $\mathrm{Rb} / \mathrm{Sr}$ ratios from lake sediments. Sci Technol Eng. 2002;3:20-2. https://doi. org/10.3969/j.issn.1671-1815.2002.03.009 (in Chinese).

Jones B, Manning DAC. Comparison of geochemical indices used for the interpretation of palaeoredox conditions in ancient mudstones. Chem Geol. 1994;111(111):111-29. https://doi. org/10.1016/0009-2541(94)90085-x.

Kelts K. Environments of deposition of lacustrine petroleum source rocks: an introduction. In: Fleet AJ, Kelts K, Talbot, editors. Lacustrine petroleum source rocks, vol. 40. Oxford: Geological Society Special Paper; 1988. p. 3-26. https://doi.org/10.1144/ gsl.sp.1988.040.01.02.

Kemp AES. Palaeoclimatology and Palaeoceanography from Laminated Sediments. London: Geological Society Special Publication; 1996. p. 1-251. https://doi.org/10.1016/s0277 -3791(97)89043-9.

Lerman A. Chemical geology and physics in lakes. Beijing: Geological Published House; 1989. p. 1-370.

Li ST. Analysis of fault basins and coal accumulation. Beijing: Geological Publishing House; 1998. p. 1-367 (in Chinese).

Li ZX. Coal Geology. Beijing: Geological Publishing House; 2005. p. 1-301 (in Chinese).

Li Y. Huangxian Formation sedimentary evolution and paragenesis of coal and oil shale in the Huangxian basin. Coal Geol China. 2013;25(6):6-10. https://doi.org/10.3969/j.issn.16741803.2013.06.002 (in Chinese).

Li ZX, Li SC, Wei JC. types of parasequence and coal accumulation of coal-bearing sequences in the Paleozoic Epicontinental Sea Basin of the western Shandong coalfield. Acta Sedimentol Sin. 1996;14(3):38-46. https://doi.org/10.14027/j.cnki. cjxb.1996.03.005 (in Chinese).

Li ZX, Wei JC, Han ML. Coal formation in transgressive events-a new pattern of coal accumulation. Adv Earth Sci. 2001;16(1):120-4. https://doi.org/10.11867/j.issn.1001-8166.2001.01.0120 (in Chinese).

Li DC, Zhu JW, Yan HR, et al. Sedimentary characteristics and distribution of oil shale in the Maoming Basin in Guangdong Province. J Jilin Univ Earth Sci Ed). 2006;36(6):938-44. https://doi. org/10.13278/j.cnki.jjuese.2006.06.012.
Li ZX, Li XJ, Li Y, et al. Mechanisms of accumulation and coexistence of coal and oil shale in typical basins. Energy Explor Exploit. 2016;34(3):360-77. https://doi.org/10.1177/0144598716631663.

Li ZX, Wang DD, Lv DW, et al. The geologic settings of Chinese coal deposits. Int Geol Rev. 2018;60(5-6):548-78. https://doi. org/10.1080/00206814.2017.1324327.

Liang WJ, Xiao CT, Xiao S. Study of relationships between paleoenvironment and paleoclimate of the Middle Permian-middle Triassic and Constant, Trace Elements in Western Sichuan. Sci Technol Eng. 2015;15(11):14-24 (in Chinese).

Liu F. Analysis of oil shale characteristics and depositional environments of the Eocene Jijuntun Formation in the Fushun Basin. Master's thesis, Jilin University, Jilin, China. 2008;1-106 (in Chinese)

Liu ZJ, Liu R. Oil shale resource state and evaluating system. Earth Sci Front. 2005;12(3):315-23. https://doi.org/10.3321/j.issn:10052321.2005.03.036 (in Chinese).

Liu R, Liu ZJ. Oil shale resource situation and multi-purpose development potential in China and abroad. J Jilin Univ Earth Sci Ed. 2006;36(6):892-8. https://doi.org/10.13278/j.cnki.jjues e.2006.06.004 (in Chinese).

Liu R. Research on oil shale characteristics and metallogenic mechanism of Cenozoic Fault Basins in Eastern Northeast Region. PhD thesis, Jilin University, Jilin, China. 2007.

Liu L, Wang DP. Depositional environments of lacustrine oil shales and their sequence stratigraphy significance. Exp Pet Geol. 1996;18(3):311-6. https://doi.org/10.11781/sysydz199603311 (in Chinese).

Liu ZX. The characteristics, genetics and resources potential of oil shale in the Dalianhe mining area of Yilan, Heilongjiang. PhD thesis, China University of Geosciences, Beijing, China. 2007;1155 (in Chinese).

Liu YJ, Cao LM, Li ZL. Elemental geochemistry. Beijing: Science Press; 1984. p. 1-540 (in Chinese).

Liu ZJ, Wang DP, Liu L, et al. Sedimentary characteristics of the Cretaceous Songliao Basin. Acta Geol Sin. 1992;66(4):327-38. https ://doi.org/10.1111/j.1755-6724.1993.mp6002005.x (in Chinese).

Liu DS, Liu JL, Lv HY. Progress in high-resolution paleoenvironment research from maar lake. Quat Sci. 1998;4:289-96 (in Chinese).

Liu CL, Xu JL, Wang PX. Algal blooms: the primary mechanism in the formation of lacustrine petroleum source rocks. Geol Rev. 2001;47(2):207-9. https://doi.org/10.16509/j.geore view.2001.02.017 (in Chinese).

Liu ZJ, Dong QS, Wang SM, et al. Introduction to continental sequence stratigraphy and application. Beijing: Petroleum Industry Press; 2002. p. 1-178 (in Chinese).

Liu ZJ, Yang HL, Dong QS, et al. Oil shale in China. Beijing: Petroleum Industry Press; 2007. p. 1-343 (in Chinese).

Liu R, Liu ZJ, Liu SY. Coal and oil shale occurrence characteristics and metallogenic regularity in Yilan Basin. J China Coal Soc. 2012a;37(5):776-81. https://doi.org/10.13225/j.cnki. jccs.2012.05.004 (in Chinese).

Liu ZJ, Meng QT, Jia JL, et al. Regularity of oil shales in Continental Basins: case study in the Meso-Cenozoic Basins of Northeast China. J Jilin Univ Earth Sci Ed. 2012b;42(5):1286-97. https:// doi.org/10.13278/j.cnki.jjuese.2012.05.003 (in Chinese).

Liu ZJ, Hu F, Sun PC, et al. Re-discussion on the four division scheme about continental sequence stratigraphy and its application on oil and gas exploration. J Jilin Univ Earth Sci Ed. 2013;43(1):1-12. https://doi.org/10.13278/j.cnki.jjuese.2013.01.010 (in Chinese).

Liu Y, Liu HY, Lv DW, et al. Paleogene coal and oil shale paragenetic association types and development features in the Huangxian Basin. China Coal Geol. 2014;26(1):10-6. https://doi. org/10.3969/j.issn.1674-1803.2014.01.02 (in Chinese).

Luo X, Zhu XM, Tan MY. Characteristics and depositional environment of oil shale, Wutu oilfield, Shandong Province. Pet Geol 
Recovery Eff. 2011;18(4):32-5. https://doi.org/10.13673/j.cnki. cn37-1359/te.2011.04.012 (in Chinese).

Lv DW, Li ZX, Liu HY, et al. The characteristics of coal and oil shale in the coastal sea areas of Huangxian coalfield, eastern China. Oil Shale. 2015;32(3):204-17. https://doi.org/10.3176/oil.2015.3.02.

Lv DW, Zong RF, Li ZX, et al. Oil shale paleo-productivity disturbed by sea water in a coal and oil shale bearing succession: a case study from the Paleogene Huangxian basin of Eastern China. J Pet Sci Eng. 2016;139:62-70. https://doi.org/10.1016/j.petro 1.2015.12.014.

Lv DW, Wang DD, Li ZX, et al. Depositional environment, sequence stratigraphy and sedimentary mineralization mechanism in the coal bed- and oil shale-bearing succession A case from the Paleogene Huangxian Basin of China. J Pet Sci Eng. 2017;148:32-51. https://doi.org/10.1016/j.petrol.2016.09.028.

McCabe PJ. Depositional models of coal and coal-bearing strata. In: Rahamani RA, Flores RM, editors. Sedimentology of coal and coal-bearing sequences, vol. 7. Rome: International Association of Sedimentologists, Special Publication; 1984. p. 13-22.

Meng QT. Research on petrologic and geochemical characteristics of eocene oil shale and its enrichment regularity, Huadian Basin. PhD thesis, Jilin University, Jilin, China. 2010;1-145 (in Chinese).

Meng QT, Liu ZJ, Hu F, et al. Productivity of Eocene ancient lakes and enrichment mechanism of organic matter in the Huadian Basin. J China Univ Pet. 2012a;36(5):38-44. https://doi.org/10.3969/j. issn.1673-5005.2012.05.007 (in Chinese).

Meng QT, Liu ZJ, Bruch AA, et al. Palaeoclimatic evolution during Eocene and its influence on oil shale mineralisation, Fushun basin, China. J Asian Earth Sci. 2012b;45:95-105. https://doi. org/10.1016/j.jseaes.2011.09.021.

Qing ZQ, Liu LW, Zheng HB (2005) Sedimentological and geochemical records of East Asian monsoon in summer upwelling region off the coast of Vietnam for the past 220000 years. Mar Geol Quat Geol 2:67-72 ((in Chinese))

Ren YJ, Wang GM, Ma ZP. Control of short-period episodic rifting to sedimentation of high-frequence cycle in continental rift-subsidence basin. Acta Sedimentol Sin. 2005;23(4):672-7. https://doi. org/10.14027/j.cnki.cjxb.2005.04.016.

Riboulleau A, Baudin F, Deconinck JF, et al. Depositional conditions and organic matter preservation pathways in an epicontinental environment: the upper Jurassic Kashpir oil shales (Volga Basin, Russia). Palaeogeogr Palaeoclimatol Palaeoecol. 2003;197:17197. https://doi.org/10.1016/s0031-0182(03)00460-7.

Sancetta C. Laminated diatomaceous sediments: controls on formation and strategies for analysis. Geol Soc. 1996;116(1):17-21. https ://doi.org/10.1144/GSL.SP.1996.116.01.03.

Shao LY, Zhang PF, Liu QF, et al. The lower Carboniferous Ceshui Formation in central Hunan, South China: depositional sequences and episodic coal accumulation. Geol Rev. 1992;38(1):52-60 (in Chinese).

Shao LY, Lu J, Wang H, et al. Developments of coal measures sequence stratigraphy in China. Acta Sedimentol Sin. 2009;27(5):904-15. https://doi.org/10.14027/j.cnki.cjxb.2009.05.010 (in Chinese).

Stach E. Translated by Yang Qi et al. Stach coal petrology course. Beijing: China Coal Industry Publishing House; 1990. p. 1-433 (in Chinese).

Stephen RS. Characteristics of shale deposition in relation to stratigraphy sequence system tracts. In: Schieber J, Zimmerle W, Sethi PS, editors. Shale and mudstones, vol. I. Stuttgart: E. Schweizerbart'sche Verlagsbuchhandlung Science Publisher; 1998. p. 109-28.

Sun PC. Environmental dynamics of organic accumulation in the oil shale bearing layers in the upper cretaceous, Southeast
Basin (NE, China), PhD thesis, Jilin University, Jilin, China. 2013;1-203.

Sun YZ, Wang BS, Lin MY. Maceral and geochemical characteristics of coal seam 1 and oil shale 1 in fault-controlled Huangxian Basin, China. Org Geochem. 1998;29(1):583-91. https://doi. org/10.1016/s0146-6380(98)00159-4.

Sun PC, Sachsenhofer RS, Liu ZJ, et al. Organic matter accumulation in the oil shale and coal-bearing Huadian Basin (Eocene; NE China). Int J Coal Geol. 2013;105:1-15. https://doi. org/10.1016/j.coal.2012.11.009.

Surdam RC, Stanley KO. The stratigaphic and sedimentologic framework of the green river formation, Wyoming. Guidebook to Annual Field Conference. 1980;205-21.

Tao MH, Han CY, Tao L. Analysis of the formational mechanisms of depositional cycles. Acta Sedimentol Sin. 2007;25(4):505-11. https://doi.org/10.14027/j.cnki.cjxb.2007.04.004 (in Chinese).

Tonger, Liu WH, Xu YC, et al. The discussion of anoxic environments and their geochemical identifying indices. Acta Geol Sin. 2004;2:365-72. https://doi.org/10.14027/j.cnki.cjxb.2004.02.026 (in Chinese).

Wang DD. Sequence-palaeogeography and coal-accumulation of the Middle Jurassic Yan' an formation in the Ordos Basin. PhD thesis, China University of Mining and Technology, Beijing, China. 2012;1-185.

Wang GM. The sedimentary control to mudstone and shale of highfrequency cycle by paleoclimate change-taking the eogene in the Jiyang depression as an example. $\mathrm{PhD}$ thesis, Chinese Academy of Sciences, Guangzhou, China. 2005;1-138. (in Chinese).

Wang DP, Liu L. Sequence stratigraphy in continental rift basins. Sediment Facies Palaeogeogr. 1994;14(3):1-9 (in Chinese).

Wang SJ, Huang XZ, Tuo JC, et al. Evolutional characteristics and the paleoclimate significance of trace elements in the Hetaoyuan Formation, Biyang depression. Acta Geol Sin. 1997;1:66-71. https://doi.org/10.14027/j.cnki.cjxb.1997.01.012 (in Chinese).

Wang BS, Li YH, Wang XE. Palaeogene transgressive lacustrine environment and coal accumulation in the Huangxian basin. Coal Geol Explor. 2000;28(3):1-12 (in Chinese).

Wang BS, Yu JF, Sun YZ, et al. Analysis of peat swamp types from the tertiary Huangxian brown coal and oil shale bearing basin. Coal Geol Explor. 2001;29(5):1-3. https://doi.org/10.3969/j. issn.1001-1986.2001.05.001 (in Chinese).

Wang KW, Zhang F, Lin DC. The control of tectonic activities on sedimentation in the Tanyuan fault depression basin. Pet Geol Eng. 2007a;21(6):7-13 (in Chinese).

Wang ZF, Lin MY, Wang BS. Maceral and geochemical characteristics of coal and oil shale in the Huanxian Basin. Coal Geol Explor. 2007b;35(4):12-5. https://doi.org/10.3969/j.issn.10011986.2007.04.004 (in Chinese).

Wang LC, Wang CS, Li YL, et al. Sedimentary and organic geochemical investigation of Tertiary lacustrine oil shale in the central Tibetan Plateau: palaeolimnological and palaeoclimatic significances. Int J Coal Geol. 2011;86(2):254-65. https://doi. org/10.1016/j.coal.2011.02.011.

Wang DD, Li ZX, Wang ZF, et al. Paleogene coal and oil shale paragenetic features and sequence stratigraphic framework in the Yilan Basin, Heilongjiang. Coal Geol China. 2013a;25(12):1-7. https ://doi.org/10.3969/j.issn.1674-1803.2013.12.01 (in Chinese).

Wang PL, Li ZX, Lv DW, et al. Analysis of palaeoclimate and metallogenic materials of typical basins under co-occurring circumstances of coal and oil shale. Coal Geol China. 2013b;25(12):812. https://doi.org/10.3969/j.issn.1674-1803.2013.12.02 (in Chinese)

Wang DD, Li ZX, Lv DW, et al. Coal and oil shale paragenetic assemblage and sequence stratigraphic features in continental faulted 
basin. Earth Sci. 2016;41(3):508-23. https://doi.org/10.3799/ dqkx.2016.042 (in Chinese).

Wei KS, Xu HD. Sequence stratigraphic features of cretaceous nonmarine sediments in the Erlian Basin. Earth Sci J China Univ Geosci. 1994;19(2):181-93 (in Chinese).

Wu CL, Yuan YB, Li SH. The synsedimentary structure framework and its controls on the thickness of extra-thick coal beds and oil shale, Fushun Basin, China. Coal Geol Explor. 1998a;26(6):2-6 (in Chinese).

Wu GX, Zhu WL, Huang ZJ, et al. Research on phytoplankton and organic matter in the lacustrine sediments and hydrocarbon source conditions. J Tongji Univ. 1998b;26(2):176-9 (in Chinese).

Xiong XH, Xiao JF. Geochemical indicators of sedimentary environments-a summary. Earth Environ. 2011;39(3):405-14. https:// doi.org/10.14050/j.cnki.1672-9250.2011.03.023 (in Chinese).

Xu SC, Dong QS, Yan LP. The characteristics and the formation mechanisms of the oil shale in the Huangxian Faulted Basin, Shandong Province. J Jilin Univ Earth Sci Ed. 2006;36(6):954-8. https://doi.org/10.13278/j.cnki.jjuese.2006.06.015 (in Chinese).

Xu SC, Liu ZJ, Dong QS, et al. Deposition and sedimentary evolution of coal, oil shale and evaporite-bearing strata in terrestrial basins. J Jilin Univ Earth Sci Ed. 2012;42(2):296-303. https:// doi.org/10.13278/j.cnki.jjuese.2012.02.002.

Xue L. Element geochemistry evaluation of paleogene source rocks in the epping depression. Master's thesis, China University of Geosciences, Beijing, China. 2013;1-76. (in Chinese).

Yan HR, Zhu JW, Li DC, et al. Formation conditions and exploitation prospects of oil shale in the Renziping Exploration Area, Qinxian Basin, Guangxi Province. J Jilin Univ Earth Sci Ed. 2006;36(6):986-90. https://doi.org/10.13278/j.cnki.jjues e.2006.06.021 (in Chinese).
Yang Q, Han DX. Geology of coal fields in China, vol. 1. Beijing: China Coal Industry Publishing House; 1979. p. 1-261 (in Chinese).

Yin XZ. Palaeolacustrine productivity study of the early Late Cretaceous in the central area of the Songliao Basin. PhD thesis, China University of Geosciences, Beijing, China, 2008;1-105. (in Chinese).

$\mathrm{Yu}$ BS. Geochemical markers of the condensed sections. Acta Mineral Sin. 1995;15(2):205-9. https://doi.org/10.16461/j.c nki.1000-4734.1995.02.014 (in Chinese).

Yu XH, Jiang H, Li SL, et al. Depositional filling models and controlling factors on mesozoic and cenozoic fault basins of terrestrial facies in Eastern China-a case study of the Dongying sag of the Jiyang Depression. Lithol Reserv. 2007;19(1):39-46 (in Chinese).

Zhang SQ, Ji YL. An approach to the sequence stratigraphic models of the fault-depression lake basin. Pet Explor Dev. 1996;23(5):20-4 (in Chinese).

Zhang DJ, Huang DF, Li JC. A preliminary study of biomarkers in Fushun and Moming oil shales and faulty coals and their geochemical significance. Pet Geol Oilfield Dev Daqing. 1985;4(2):1-18. https://doi.org/10.19597/j.issn.1000-3754.1985.02.001 (in Chinese)

Zhou ZQ, Dong QS, Hou GF, et al. The forming environment and sedimentary evolution of the oil shale intergrowth with salt alkali mine-with the oil shale deposit of Wucheng, Tongbai Basin as an example. J Jilin Univ Earth Sci Ed. 2006;36(6):1001-5. https:// doi.org/10.13278/j.cnki.jjuese.2006.06.024 (in Chinese).

Zhu GY, Jin Q, Zhang SC, et al. Characteristics and origin of deep lake oil shale of the paleogene shahejie formation in the Dongying sag, Jiyang Depression. J Palaeogeogr. 2005;7(1):59-70. https ://doi.org/10.3969/j.issn.1671-1505.2005.01.006 (in Chinese). 